\title{
The Changing Effects of Agro-Climate on Cereal Crop Yields during the Green Revolution in India, 1972 to 2002
}

\author{
Takuji W. Tsusaka ${ }^{1} \&$ Keijiro Otsuka ${ }^{2}$ \\ ${ }^{1}$ International Rice Research Institute, Philippines \\ ${ }^{2}$ National Graduate Institute for Policy Studies, Japan \\ Correspondence: Keijiro Otsuka, National Graduate Institute for Policy Studies, Japan. E-mail: \\ otsuka@grips.ac.jp
}

Received: February 7, 2013 Accepted: March 8, 2013 Online Published: March 12, 2013

doi:10.5539/jsd.v6n4p11 URL: http://dx.doi.org/10.5539/jsd.v6n4p11

\begin{abstract}
Conventionally, agricultural technologies associated with the Asian Green Revolution (GR) have been regarded as a resource-demanding type of technologies which achieve higher crop yields by intensive use of inputs including water, but are therefore sensitive to harsh agro-ecological conditions such as droughts. This study uniquely explores the changes over time in the impacts of climatic conditions and irrigation on cereal crop yields in India during the 31-year period from 1972 to 2002. A district-level panel data set is assembled from several sources, and the yield equations for five major crops (wheat, rice, maize, sorghum, pearl millet) are estimated by combining two-way fixed effect and sample selection models. It is found that climate dependence of crop yields decreased over time, particularly at the later stage of the GR, indicating that GR technologies for these cereal crops have mitigated, rather than aggravated, the adverse effects of climatic conditions on crop yields. Moreover, it is also found that the adoption of irrigation leads not only to directly enhancing crop yields but also to alleviating the negative influences of temperature and rainfall. The results suggest that recent agricultural technologies developed in Asia can be conducive to overcoming harsh production environments in less-favored regions of the world, if proper institutions are in place.
\end{abstract}

Keywords: Green Revolution, crop yield, modern variety, wheat, rice, maize, sorghum, millet, agro-climate, irrigation, drought tolerance, heat tolerance, panel data, two-way fixed effect, India

JEL Classification: O13, Q56

\section{Introduction}

Agricultural productivity growth is undoubtedly a crucial factor for reducing rural poverty and achieving food security in low-income countries (World Bank, 2008). Although the notion of the role of agriculture has changed over time, the dominant paradigm since the 1970s has seen agriculture as an "engine of growth" in the early stages of economic development because of its high share of economic activities and its strong growth linkages with the rest of the economy, including the rural nonfarm sector. For instance, econometric analysis over the recent two decades for 42 developing countries shows that a 1 percent growth in agricultural GDP increases the incomes of the poorest deciles in the expenditure distribution by more than 2.5 percent. Among the poor with slightly higher income, the effect of agricultural growth on poverty reduction is found to decrease but to remain superior to that of non-farm activities (Christiaensen \& Demery, 2012). Byerlee, Diao and Jackson (2005) also review case studies on twelve developing countries around the world, and confirm the contribution of the agricultural sector to pro-poor growth.

In Asia, growth in agricultural production has consistently outpaced population growth (Otsuka \& Kalirajan, 2006), which is in sharp contrast with the stagnant growth in Africa. The success in Asia is not only because population growth has been somewhat slower, but much more importantly because the technological innovation represented by the adoption and diffusion of improved crop varieties and complementary production practices spurred agricultural yields in Asia, which has led to significant reductions in rural poverty as well as the growth of nonfarm sectors (Otsuka, Estudillo, \& Sawada, 2009; Lipton, 2007; Otsuka \& Yamano, 2005). The adoption rate for improved crop varieties reached about 70 percent of wheat and rice fields in Asian developing countries by 1990 . Moreover, as international agricultural research centers that are designed to work on other crops were 
established, improved varieties of other major food crops were subsequently developed and disseminated. These technological changes more than doubled cereal production in Asia by the late 1980s while the population increased by 60 percent (Lipton \& Longhurst, 1989). As a consequence, instead of widespread famine, caloric intake per capita increased by nearly 30 percent, and wheat and rice became cheaper (Rosegrant \& Hazell, 2000). This agricultural innovation in Asia is termed the Green Revolution (hereinafter called GR). A critically important point is that the doubling of cereal production in Asia has been attained with only a 4 percent increase in crop area, which was a dramatic departure from historical trends (Hazell, 2001).

In Africa, one of the major hindrances is considered to be its harsh climatic conditions, since climate typically represented by temperature and rainfall has a direct impact on agricultural production. (Note 1) A bunch of empirical studies have found the significant effects of climatic conditions, particularly the positive impact of precipitation (Deschênes \& Greenstone, 2007; Seo \& Mendelsohn, 2007; Schlenker \& Roberts, 2006; Auffhammer, Ramanathan, \& Vincent, 2006; Olesen \& Bindi, 2002; Sanghi, Mendelsohn, \& Dinar, 1998; Bruce, Yi, \& Haites, 1996; Reilly et al., 1996; Adams et al., 1995). Low levels of inputs (water from rainfall and irrigation, and fertilizer) can seriously undermine the performance of high-yielding varieties that typically rely on high-input production environments (Cavatassi, Lipper, \& Barloch, 2011; Farmer, 1979).

While it has conventionally been recognized that Asian GR technology is sensitive to agro-climates and its adoption generally results in aggravating the adverse effect of droughts and other harsh climatic conditions on crop yields, some descriptive studies argue that the adverse effects of unfavorable production environments could be lessened by relatively new technological changes. For instance, Byerlee (1996) points out that in India, although modern varieties (MVs) of cereal crops were introduced primarily in irrigated areas in the early stage of the GR, the technology adoption rate in non-irrigated areas started to rise in the later stage as technology continued to improve so that it could better adapt to unfavorable conditions. Similarly, Fan and Hazell (1999) found for rural India that the rain-fed areas, including many less-favored areas, exhibited higher agricultural growth for an additional unit of public investment than did irrigated areas, in the later stage of the GR. If, as these descriptive studies suggest, the adoption of recent MVs leads to a reduction in the climate dependence of crop yields, then that would result in a positive factor for yield growth in semi-arid and other unfavorable agricultural production environments. However, concrete empirical evidence has been scanty to support this argument.

In this context, this paper aims to provide a solid evidence as to whether and to what extent the influence of climatic conditions on cereal crop yields has been augmented or alleviated, if any, by GR technology, irrigation, and other factors changing over time during the GR period from the early 1970s to the early 2000s, using a district-level thirty-one-year panel dataset, which has been constructed from various sources. Investigating India's experience is also useful to draw lessons for SSA, because there are similarities in agricultural production environment between India and SSA, such as the cropping patterns, diverse agro-climate, differing poverty incidence, and the dominance of peasants. To our knowledge, studies on the dynamic changes in agro-climate effects on crop yields are scarce, even though there are a number of studies exploring the static effects of climate and climate change on crop yields.

The rest of this paper is organized as follows: section two provides an overview of the historical performance and current state of cereal production in India with an outline of our hypotheses. Section three describes our data sources and database construction, followed by the introduction of econometric models. The regression results are carefully examined in section four, while section five analyzes the early GR period during which the MV adoption rate was highly correlated with irrigation diffusion rate. Lastly, section six presents concluding remarks.

\section{An Overview of Cereal Crop Production in India}

\subsection{Investment Trend}

By the time the GR began taking place in the late 1960s, gravity irrigation was available in some parts of India, and road conditions had been considerably improved, which had set the stage for the adoption of GR technologies (Rosegrant \& Hazell, 2000; Bhalla \& Singh, 2001). Then, further massive investments were made in rural areas during the GR period, when MVs were diffused and, subsequently, small-scale irrigation schemes with pumps and tubewells were introduced. Public investments in rural areas grew at a rate of about 13 percent annually during the 1970s and increased fivefold by the end of the 1980s, which led to phenomenal rural poverty reduction in India (Fan, Hazell, \& Thorat, 2000; Fujita, 2010). The steady growth in irrigation investments resulted in a nearly twofold increase in the area under irrigation by the 1990s (Johnson, Hazell, \& Gulati, 2003). 


\subsection{Cropping Patterns}

India consists of thirty-five states (including union territories) with diverse cropping patterns reflecting its diverse agro-climate. Table 1 shows the proportions of harvested areas of five major crops grown in India, with reference to other Asia and SSA, over the period of 2003-07. The crop composition in other Asia is skewed to rice, whereas sorghum and millet have large shares in SSA. India stands in-between the two regions, with relatively diverse cropping patterns, which reflects the similarity in agro-climate between some parts of India and SSA, and between other parts of India and other Asia.

Table 1. Proportions of harvested area by cereal crop (\%), 2003-2007 Average

\begin{tabular}{lccc}
\hline & SSA & India & Other Asia \\
\hline Wheat & 3 & 27 & 32 \\
Rice & 10 & 44 & 42 \\
Maize & 34 & 8 & 18 \\
Sorghum & 24 & 9 & 1 \\
Millet & 23 & 12 & 1 \\
Others* & 6 & 1 & 6 \\
\hline Total & 100 & 100 & 100 \\
\hline
\end{tabular}

*Others: Ragi, Oats, Barley, Cassava, Teff, etc.

Source: Authors' calculation with FAOSTAT data.

\subsection{Cereal Yields}

Figure 1 compares the average cereal yields between India and SSA, as well as Southeast Asia. The most important finding is that despite the more favorable production environments, cereal crop yield in India was not significantly superior to that in SSA up to the early 1980s. As can be seen, however, the yields in the two regions started to diverge in the mid-1980s and today the gap is approximately two-fold. These observations indicate that before the GR, i.e., without modern technology, the productivity of cereal crops was not significantly different between the two regions. Nonetheless, since climate has changed only a little, it is obvious that the yield divergence occurred primarily due to the adoption of modern technology in Asia.

India's crop-wise yield growth is shown in Figure 2. It is noticeable that the yields of rice, wheat and maize have soared dramatically over the last several decades. Although less dramatic, the yields of sorghum and millet have almost doubled, which is consistent with the finding by Pray and Nagarajan (2010), who argue that the production technologies for these crops, including modern varieties, have improved significantly. Nonetheless, the absolute yields for sorghum and millet in India (shown in Figure 2) are not superior to those in SSA (shown in, e.g., Tsusaka \& Otsuka, 2013a), indicating that there would be limited transferability of technology for these two crops from Asia to SSA, as India is almost the only Asian country that produces these crops. 


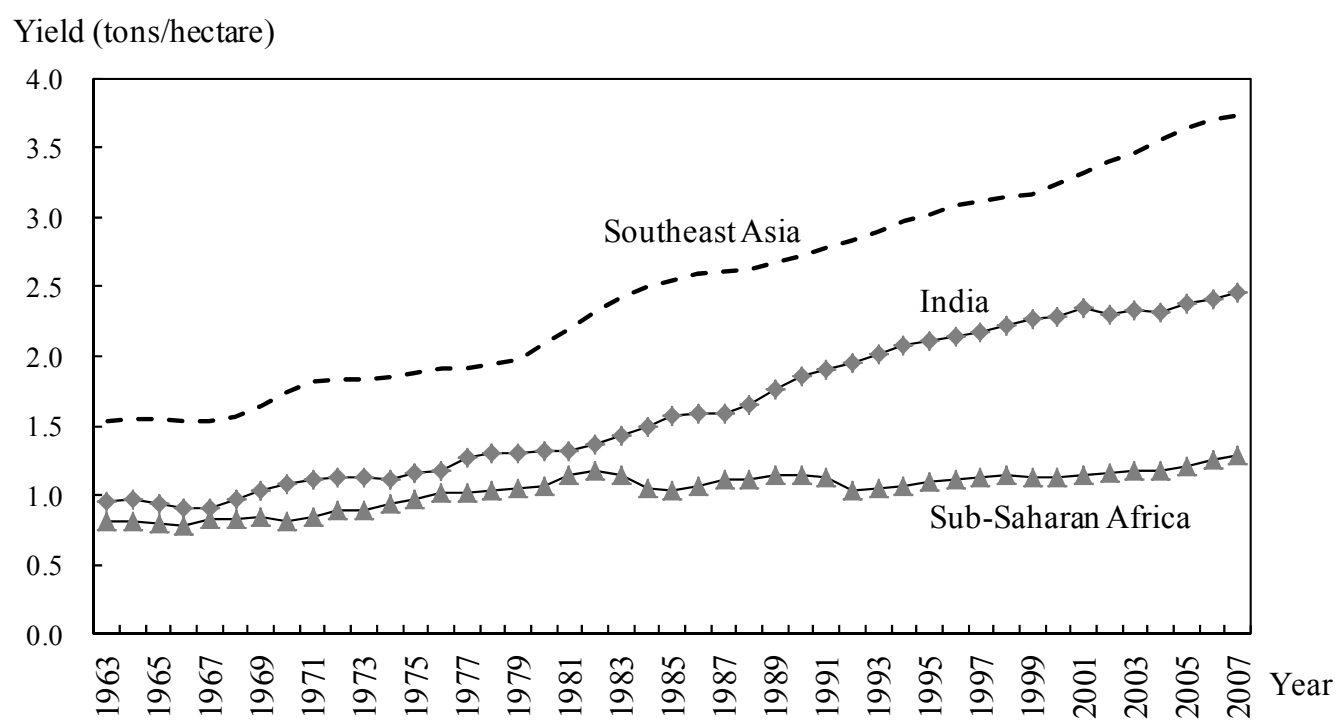

Figure 1. Average cereal yields in India, Southeast Asia, and SSA, 3-year moving averages Source: Authors' calculation with FAOSTAT data.

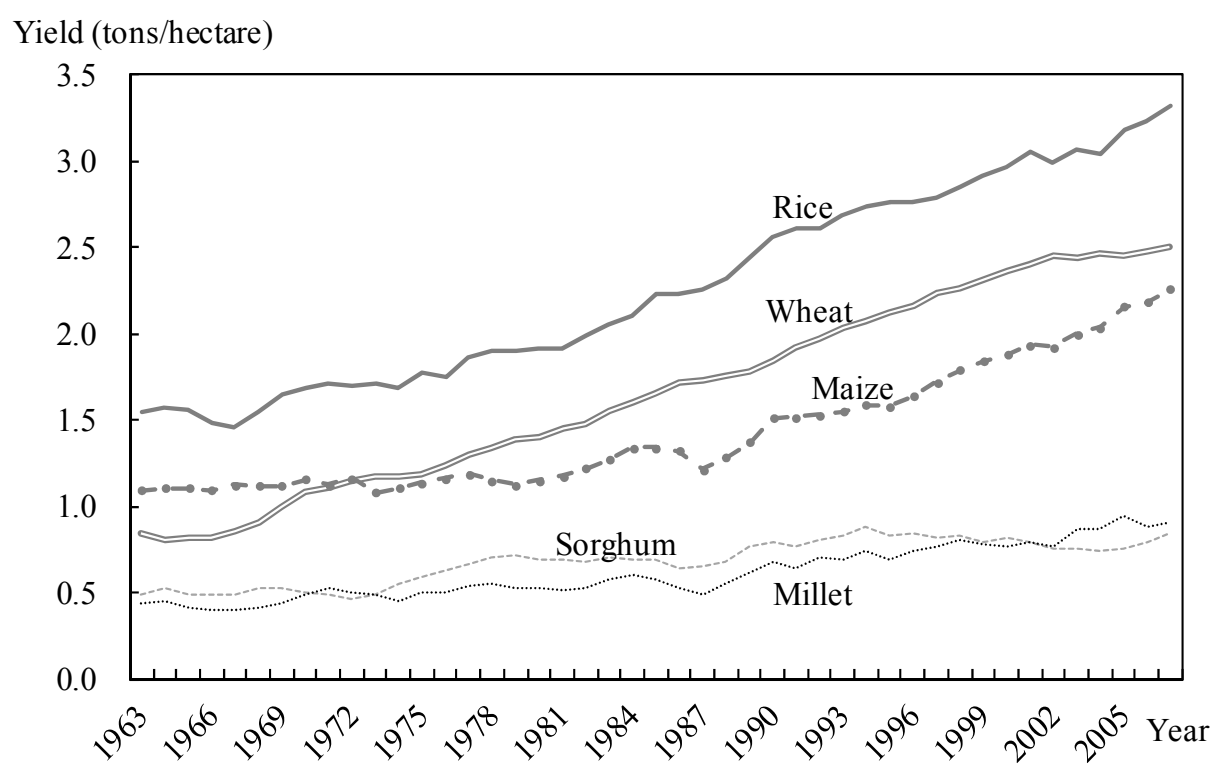

Figure 2. Cereal yields in India by Crop, 3-year moving averages

Source: Authors' calculation with FAOSTAT data.

\subsection{Changes in Cropping Patterns}

Figure 3 shows how cropping patterns have been evolving in India. It is observed that farmers in India have been increasing the area planted to rice, wheat, and maize, whose yields have been rising. Since the total harvested area has remained largely unchanged, it seems clear that farmers have been replacing sorghum and millet with these three crops. Thus, India has been feeding its increasing population not only by raising the yield of various crops but also by switching crops from low performing crops (sorghum and millet) to high performing crops (rice, wheat, and maize) (Note 2). 


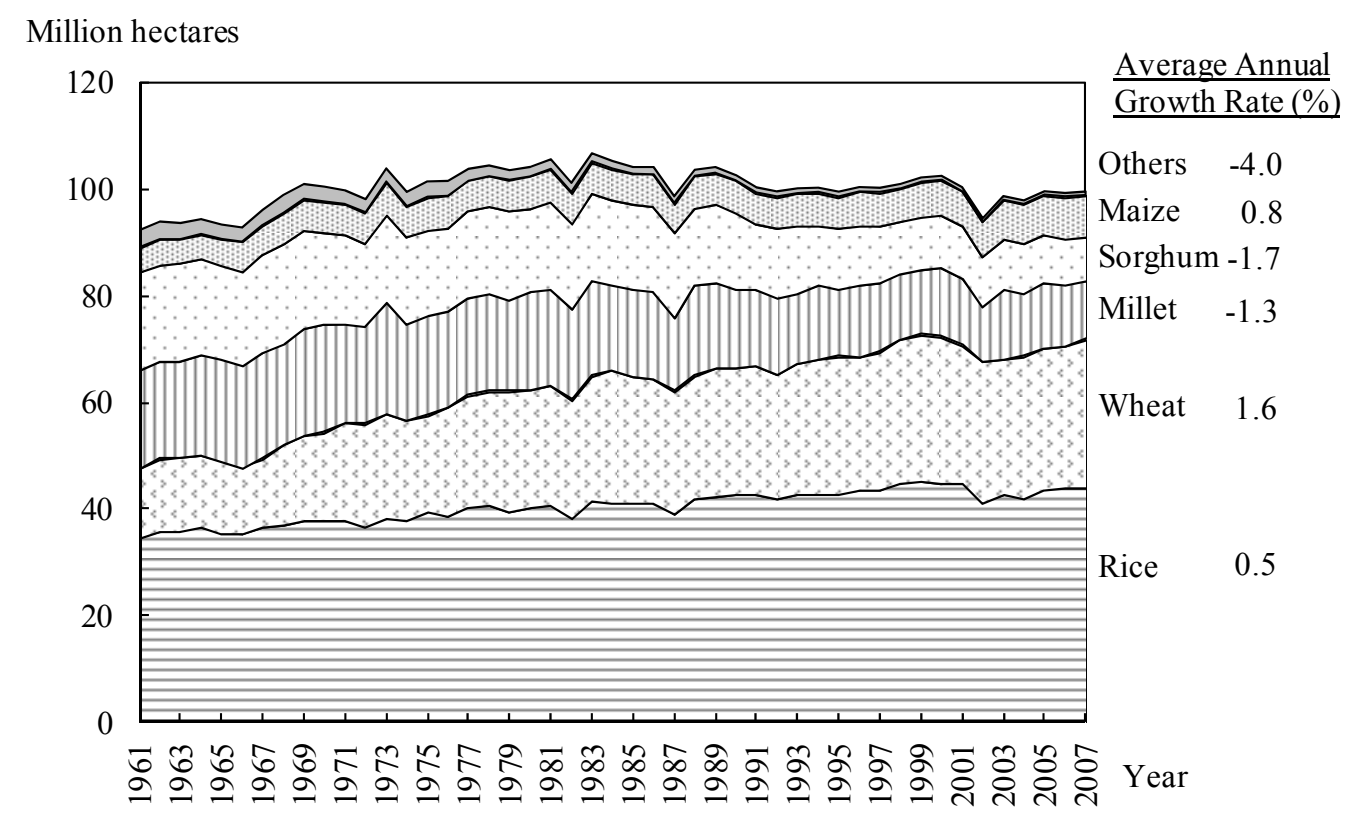

Figure 3. Changes in harvested area by cereal crop in India

Source: Authors' calculation with FAOSTAT data.

\subsection{Irrigation Expansion}

The availability of irrigation is considered to be crucial for crop yield performance (see, e.g., David \& Otsuka, 1994). According to Figure 4, the proportion of irrigated area for wheat is considerably high, which is consistent with the study by Singh and Jain (2000). Irrigation coverage for rice fields has been rising, while it has been more or less constant at low levels for maize, sorghum, and millet. The impacts of irrigation on crop productivity are likely to be higher for wheat and rice than for other cereals.

Gravity irrigation, which is constructed by the public sector, was the most popular form of irrigation (Ostrom, 1990) particularly in the early stage of the GR. In the later stage, tubewell and pump irrigation, which can be installed by farmers, became increasingly common. Figure 4 shows, however, that the increment in irrigation coverage, which is supposedly provided by tubewell, is small relative to the original level which mostly consists of gravity type. Although Figure 4 does not distinguish the types of irrigation, it seems evident that gravity irrigation continuously played an important role in India throughout the GR period (Note 3).

A question may arise as to whether the marginal effects of irrigation on crop yields have been changing over time along with the adoption of improved crop varieties as well as other farming technologies. If the new technologies are less dependent on a stable supply of water, the effect of irrigation may decline. On the other hand, it may increase if intensification of wheat and rice farming systems requires more intensive use of irrigation water. It would also be of interest to investigate how the effect of irrigation interacts with the effects of temperature and rainfall on crop yields, for which Tables $2 \mathrm{a}$ and $2 \mathrm{~b}$ suggest a substitution relationship between irrigation and rainfall. 


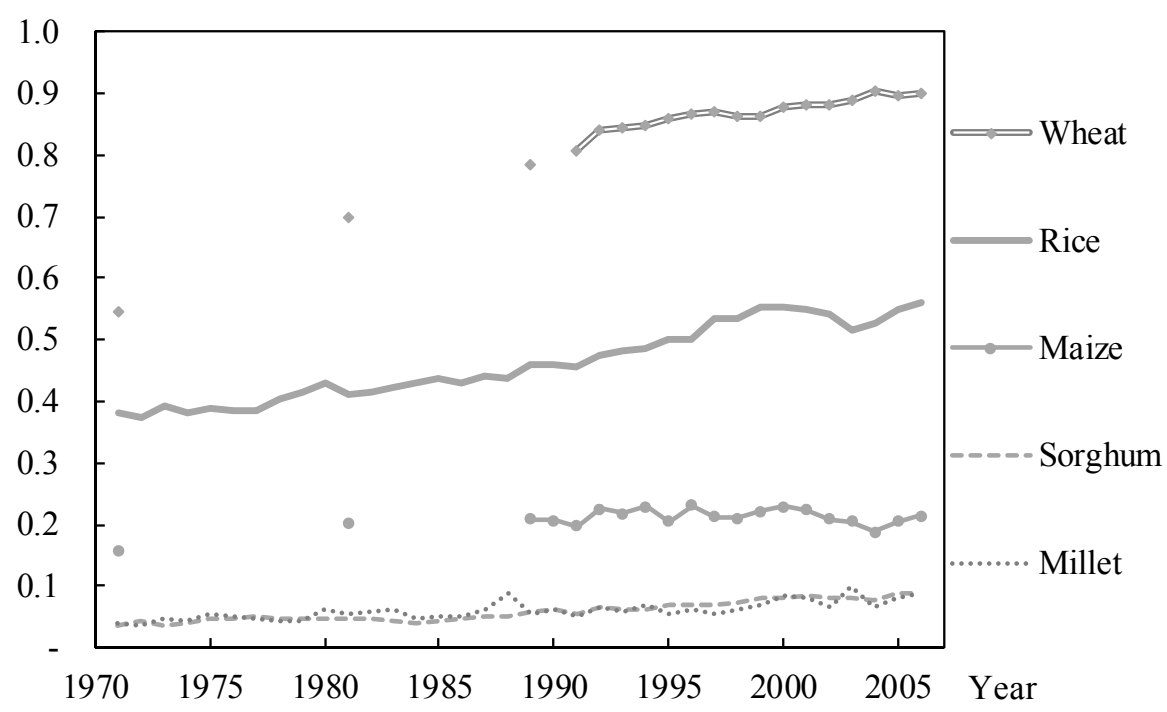

Figure 4. Proportion of irrigated area by crop in India

Source: Authors' calculation, Center for Monitoring Indian Economy.

\subsection{Modern Variety Adoption}

Figure 5 shows the changes in MV adoption rate by crop. What seems striking is that the adoption rates of MVs have been increasing rapidly, even for sorghum and millet toward 2000, which confirms the report by Pray and Nagarajan (2010). As is emphasized by Estudillo and Otsuka (2011), the quality of MVs has also improved over time. The data in Figure 5, however, do not distinguish quality. Also unclear is the impact of MVs of sorghum and millet on their yields, as this has seldom been reported in the economic literature (Note 4).

A potentially important trait of MVs is their shortened growth duration (Cavatassi, Lipper, \& Barloch, 2011; Khush, 2001; Hossain \& Fischer, 1995; Lawn, 1989), allowing cereal crops to mature in a shorter period during which rainfall is somewhat assured. For example, the latest rice MVs mature in 105 to 110 days, which is considerably shorter than the growth duration of 160 to 170 days of traditional rice varieties (TVs) in Asia (Khush, 2001). If so, it seems reasonable to hypothesize that the adoption of MVs lessens the impact of precipitation on rice yields. However, the problem is that our data set contains only India's national and state-level MV adoption rates by crop, not at the district level. In the absence of proper data for district-level MV adoption, we are unable to perform a direct analysis of the impact of MV adoption directly on crop yields and indirectly through climate effects. Even so, fairly strong supportive results are presented in this study. 


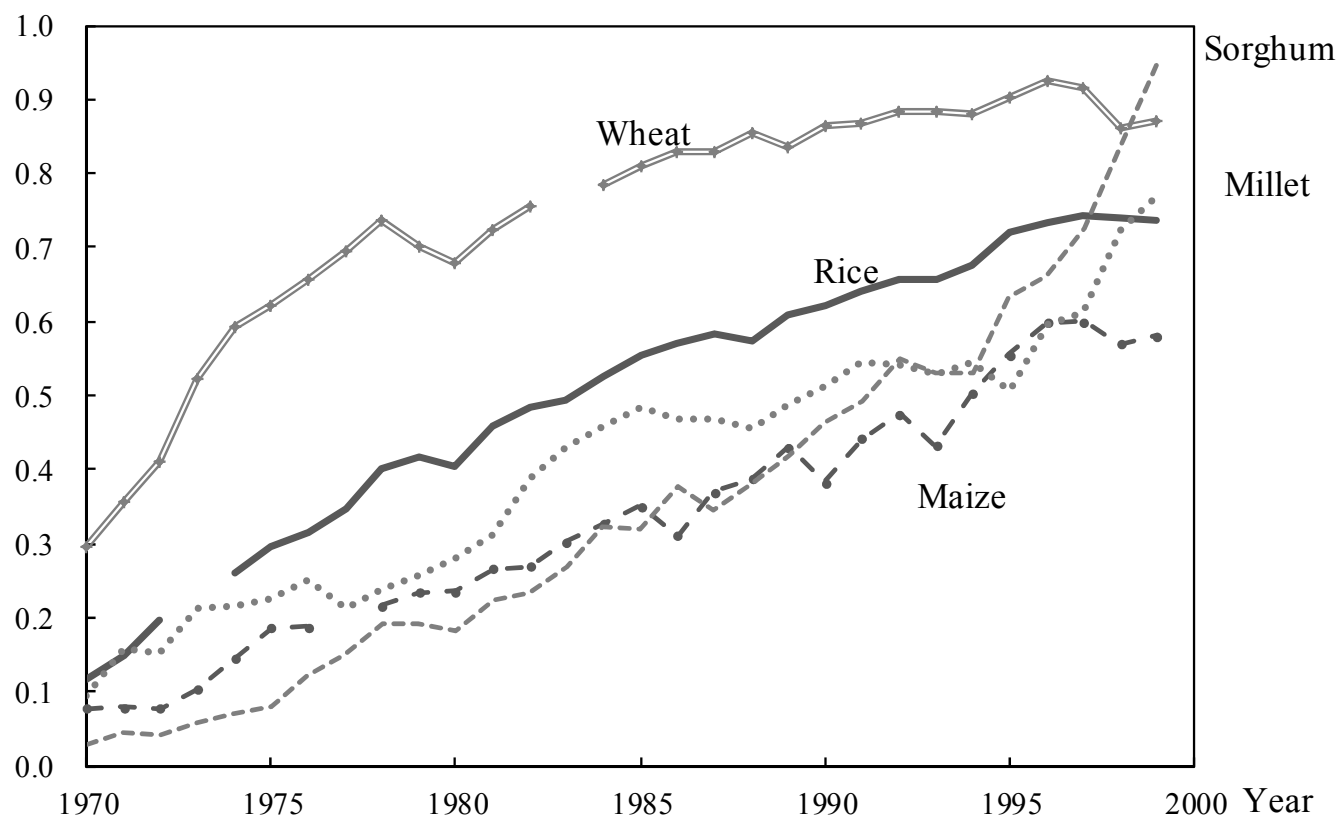

Figure 5. Proportion of area sown to modern varieties by crop

Source: Authors' calculation, Center for Monitoring Indian Economy.

\subsection{Environment and Crop Choice}

Table 2a. Yield, climate, and irrigation coverage in India, by crop, 1998-2002 five-year average

\begin{tabular}{|c|c|c|c|c|c|c|c|c|c|c|}
\hline & \multicolumn{2}{|c|}{ Wheat } & \multicolumn{2}{|c|}{ Rice } & \multicolumn{2}{|c|}{ Maize } & \multicolumn{2}{|c|}{ Sorghum } & \multicolumn{2}{|c|}{ Millet } \\
\hline Grouping by Irrigation & \multicolumn{2}{|c|}{ Average } & \multicolumn{2}{|c|}{ Average } & \multicolumn{2}{|c|}{ Average } & \multicolumn{2}{|c|}{ Average } & \multicolumn{2}{|c|}{ Average } \\
\hline Coverage Ratio ${ }^{a b}$ & Low & High & Low & High & Low & High & Low & High & Low & High \\
\hline \multirow{2}{*}{ Temperature $\left({ }^{\circ} \mathrm{C}\right)^{\mathrm{c}}$} & \multicolumn{2}{|c|}{25.3} & \multicolumn{2}{|c|}{25.5} & \multicolumn{2}{|c|}{25.6} & \multicolumn{2}{|c|}{26.3} & \multicolumn{2}{|c|}{26.2} \\
\hline & 23.4 & 25.7 & 24.9 & 26.0 & 25.4 & 26.0 & 26.3 & 25.9 & 26.2 & 26.4 \\
\hline \multirow{2}{*}{ Rainfall $(\mathrm{mm})^{\mathrm{c}}$} & \multicolumn{2}{|c|}{852} & \multicolumn{2}{|c|}{1,007} & \multicolumn{2}{|c|}{863} & \multicolumn{2}{|c|}{848} & \multicolumn{2}{|c|}{794} \\
\hline & 1,045 & 809 & 1,127 & 920 & 895 & 802 & 877 & 658 & 811 & 701 \\
\hline Irrigation Coverage & \multicolumn{2}{|c|}{79} & \multicolumn{2}{|c|}{58} & \multicolumn{2}{|c|}{34} & \multicolumn{2}{|c|}{14} & \multicolumn{2}{|c|}{18} \\
\hline Ratio $^{a}(\%)$ & 23 & 92 & 17 & 90 & 10 & 81 & 4 & 82 & 6 & 83 \\
\hline \multirow{2}{*}{ Yield (kg/ha) } & \multicolumn{2}{|c|}{2,153} & \multicolumn{2}{|c|}{2,007} & \multicolumn{2}{|c|}{1,825} & \multicolumn{2}{|c|}{821} & \multicolumn{2}{|c|}{1,001} \\
\hline & 1,203 & 2,365 & 1,418 & 2,455 & 1,630 & 2,198 & 720 & 836 & 964 & 1,207 \\
\hline \multirow{2}{*}{ No. of Districts } & \multicolumn{2}{|c|}{356} & \multicolumn{2}{|c|}{412} & \multicolumn{2}{|c|}{327} & & & & 59 \\
\hline & 65 & 291 & 178 & 234 & 215 & 112 & 224 & 34 & 228 & 41 \\
\hline
\end{tabular}

a. $\quad$ Irrigation Coverage = Irrigated Area's Percentage of Area Sown to Each Crop.

b. High referes to coverage of more than 50 percent and Low refers to coverage of less than 50 percent.

c. In India, wheat is cultivated primarily in the rabi season when temperature and rainfall are lower than in the other seasons. Thus, note that the presented annual climate overstates the actual wheat-growing environment. The discussion applies, in particular, to rainfall because most of the rainfall is observed in the summer monsoon season whereas temperature is ralatively stable across seasons.

Source: Authors' calculation with India Water Portal's data and Center for Monitoring Indian Economy's database. 
Table 2a shows the five-year averages of temperature, rainfall, irrigation coverage rate, and crop yields, over the districts where each crop is grown, for the years 1998 to 2002. Temperature in crop-producing districts is largely the same across crops, though it is slightly higher for sorghum and millet. Rainfall varies and it is notably higher in rice-growing districts, suggesting that rainfall plays an important role in rice cultivation. Judging from the low rainfall and irrigation coverage, it is understood that sorghum and millet have comparative advantages in drier environments. The lower section of each box in the table shows statistics calculated for two groups: high and low in irrigation ratio, where for convenience high refers to above $50 \%$ and low refers to below $50 \%$ of the total sown area for each crop. There are two major observations. First, in the regions with high irrigation coverage, rainfall is lower, and vice versa, for all five major crops, which is not of much surprise if irrigation is designed to help compensate for inadequate rainfall. Second, even in the regions with lower rainfall, the availability of irrigation results in higher yields than in the regions with higher rainfall, particularly for wheat and rice, followed by maize and millet, but not for sorghum. These observations are mostly consistent with the differences in irrigation coverage among the five crops shown in Figure 4.

Table $2 \mathrm{~b}$ demonstrates the same statistics as in Table $2 \mathrm{a}$ but for the early 1970 s, which corresponds to the early stage of the GR in India. We can ignore regions with high irrigation coverage for sorghum and millet, as there were only a few such districts at that time. Again, irrigation coverage and crop yields are positively linked, but not as clearly as in the early 2000s. These observations are suggestive of the increasingly decisive role if irrigation in enhancing crop yields in low-rainfall environments. Thus, the comparison of Tables $2 \mathrm{a}$ and $2 \mathrm{~b}$ suggests a hypothesis that the impact of irrigation on crop yields has increased over time with the adoption of GR technologies.

Table 2b. Yield, climate, and irrigation coverage in India, by crop, 1972-76 five-year average

\begin{tabular}{|c|c|c|c|c|c|c|c|c|c|c|}
\hline & \multicolumn{2}{|c|}{ Wheat } & \multicolumn{2}{|c|}{ Rice } & \multicolumn{2}{|c|}{ Maize } & \multicolumn{2}{|c|}{ Sorghum } & \multicolumn{2}{|c|}{ Millet } \\
\hline Grouping by Irrigation & \multicolumn{2}{|c|}{ Average } & \multicolumn{2}{|c|}{ Average } & \multicolumn{2}{|c|}{ Average } & \multicolumn{2}{|c|}{ Average } & \multicolumn{2}{|c|}{ Average } \\
\hline Coverage Ratio & Low & High & Low & High & Low & High & Low & High & Low & High \\
\hline \multirow{2}{*}{ Temperature $\left({ }^{\circ} \mathrm{C}\right)$} & \multicolumn{2}{|c|}{25.2} & \multicolumn{2}{|c|}{25.5} & \multicolumn{2}{|c|}{25.5} & \multicolumn{2}{|c|}{25.8} & \multicolumn{2}{|c|}{25.8} \\
\hline & 25.2 & 25.3 & 25.4 & 25.7 & 25.5 & 25.6 & 25.8 & 24.6 & 25.7 & 26.5 \\
\hline \multirow{2}{*}{ Rainfall (mm) } & \multicolumn{2}{|c|}{996} & \multicolumn{2}{|c|}{1,072} & \multicolumn{2}{|c|}{1,003} & \multicolumn{2}{|c|}{950} & \multicolumn{2}{|c|}{911} \\
\hline & 868 & 1,134 & 963 & 1,138 & 898 & 1,032 & 735 & 961 & 801 & 916 \\
\hline Irrigation Coverage & \multicolumn{2}{|c|}{52} & \multicolumn{2}{|c|}{41} & \multicolumn{2}{|c|}{25} & \multicolumn{2}{|c|}{8} & \multicolumn{2}{|c|}{6} \\
\hline Ratio (\%) & 23 & 78 & 15 & 86 & 10 & 78 & 3 & 73 & 3 & 66 \\
\hline \multirow{2}{*}{ Yield (kg/ha) } & \multicolumn{2}{|c|}{1,243} & \multicolumn{2}{|c|}{1,045} & \multicolumn{2}{|c|}{1,093} & \multicolumn{2}{|c|}{570} & \multicolumn{2}{|c|}{532} \\
\hline & 1,036 & 1,430 & 858 & 1,368 & 1,041 & 1,276 & 568 & 601 & 522 & 752 \\
\hline \multirow{2}{*}{ No. of Districts } & \multicolumn{2}{|c|}{211} & \multicolumn{2}{|c|}{205} & \multicolumn{2}{|c|}{187} & & 59 & & 52 \\
\hline & 100 & 111 & 130 & 75 & 146 & 41 & 159 & 10 & 145 & 7 \\
\hline
\end{tabular}

Footnote for Table 2a applies.

Source: Authors' calculation with India Water Portal's data and Center for Monitoring Indian Economy's database.

\section{Database Construction and Empirical Methodology}

\subsection{Data Source}

One unique aspect of this research is to quantify the changes over time in the effects of various factors on yields by crop and, in particular, the climate effects, using district-level panel data. The data set covers 270 main districts and many small others over a period of 31 years from 1972 to 2002. The important variables are crop yields, i.e., the quantity of agricultural output divided by the respective planted areas for five major crops (wheat, rice, maize, sorghum, and millet), climatic conditions represented by temperature and rainfall, irrigation coverage ratio by crop, and district specific characteristics (population density and literacy rate). The database is composed of several different sources, both public and private. Data on agricultural outputs, land, and rainfall are purchased from the CMIE (Center for Monitoring Indian Economy Limited). Temperature data are collected 
through the Water Portal Service powered by India's Meteorological Department. (Note 5) Some district characteristics data are obtained from Indiastat Service provided by Datanet India particularly for recent years. (Note 6) Other district characteristics data are cordially provided by Drs. Zhang and Fan of the International Food Policy Research Institute. Detailed agricultural data for years 1958 to 1986 are available through the database assembled by Dr. Kumar of the World Bank (http://ipl.econ.duke.edu/dthomas/dev_data/) (Note 7).

\subsection{Selection Equation for Each Crop}

Once the database is constructed, the next step is to assess the changing effects of climatic conditions (as represented by temperature and rainfall) and irrigation on crop yields. The effects of other factors such as population density and literacy rate are also considered.

First, it may be necessary to address possible sample selection bias since each crop is grown in many districts but not in all. Therefore, the estimation procedure consists of two steps. (Note 8) The first step employs probit regressions to estimate the selection equation for each crop, from which the inverse Mills ratio is calculated (Heckman, 1797). (Note 9) The set of explanatory variables includes short-term normal climate represented by three-year moving averages of rainfall and temperature over the preceding years. (Note 10) The selection equation can be specified as follows:

$$
\mathrm{y}_{\mathrm{ijt}}=\left\{\begin{array}{rr}
1 & \text { if } \mathrm{y}_{\mathrm{ijt}}{ }^{*}>0 \\
0 & \text { otherwise }
\end{array}\right.
$$

and

$$
y_{i j t}^{*}=\beta_{1 i} \overline{\operatorname{temp}}_{j t}+\beta_{2 i} \overline{\operatorname{temp}}_{j t}{ }^{2}+\beta_{3 i} \overline{\text { rain }}_{j t}+\beta_{4 i} \overline{\text { rain }}_{j t}{ }^{2}+\beta_{5 i} \operatorname{stdev}(\text { rain })_{j t}+\beta_{6 i} i_{\text {irri }}{ }_{j t}+\beta_{7 i} \text { lit }_{j t}+\beta_{8 i} \text { popden }_{j t}+\varepsilon_{i j t},
$$

where $y_{i j t}$ is 1 if crop $i$ is grown in district $j$ in year $t$, and 0 otherwise; $\overline{\text { temp }}_{j t}$ and $\overline{\text { rain }}_{j t}$ represent the short-term normal climate in terms of temperature and rainfall, respectively; $\operatorname{stdev}(\text { rain })_{j t}$ is the short-term standard deviation of rainfall over the preceding three years; irri $_{j t}$ is the district's irrigation coverage ratio (Note 11 ), lit $_{j t}$ is the literacy rate; popden ${ }_{j t}$ is the population density (Note 12), and $\varepsilon_{i j t}$ is the normally distributed error term. Finally, the inverse Mills ratio is calculated from the result of this estimation to be included in the outcome equation.

\subsection{Yield Equations: Two-Way Fixed Effect Model}

The second step is to assess the changing effects of climatic factors on cereal crop yields, for which the basic estimation model can be specified as follows:

$$
\begin{aligned}
& Y_{i j t}=\sum_{k=1}^{m} \alpha_{0 k i} C_{j t}^{k}+\sum_{k=1}^{m} \alpha_{1 k i} C_{j t}^{k} \cdot t+\sum_{k=1}^{m} \alpha_{2 k i} C_{j t}^{k} \cdot t^{2}+\beta_{i} C_{j t} \cdot \operatorname{irri}_{i j t}+\gamma_{0 i} i r r i_{i j t}+\gamma_{1 i} i r r i_{i j t} \cdot t \\
& +\gamma_{2 i} i r r i_{i j t} \cdot t^{2}+\zeta_{0 i} X_{j t}+\zeta_{1 i} X_{j t} \cdot t+\zeta_{2 i} X_{j t} \cdot t^{2}+\eta_{1 i} t+\eta_{2 i} t^{2}+\theta_{i} \tau_{t}+\rho_{i} \lambda_{i j t}+v_{i j}+\varepsilon_{i j t}
\end{aligned}
$$

Where $Y_{i j t}$ is the yield of crop $i$ in district $j$, and year 1972+t (e.g., $t=0$ for year 1972 and $t=30$ for year 2002); $C_{j t}$ is a vector of climate variables (temperature and rainfall); $\operatorname{irri}_{i j t}$ is the crop-specific irrigation coverage ratio (Note 13); $X_{j t}$ is a vector of district characteristics (population density and literacy rate); $\tau_{t}$ is a vector of year dummies; $\lambda_{i j t}$ is the inverse Mills ratio obtained from the first-step probit estimation; $v_{i j}$ is the unobservable time-invariant district-specific effect; and $\varepsilon_{i j t}$ is the error term. Finally and very importantly, the interaction terms between the explanatory variables and the time trend variables (i.e., $t$ and $t^{2}$ ) are included to examine whether there have been changes over time in the impacts of those explanatory variables due to changes in technology and other factors, e.g., the introduction of short-maturity and drought-tolerant MVs. The index $m$ indicates up to what order the climate variables are to be included in the equation. In the subsequent analysis, $m$ is either 1 or 2, which correspond to a linear model and a nonlinear model, respectively. The time trend $(t)$ and its squared term $\left(t^{2}\right)$ are also included with an aim to capture the independent effect of technology improvement over time and its acceleration (or deceleration) that are not picked up by the changes over time in the effects of the explanatory variables. (Note 14) The effect of population density is also a thought provoking subject. If the effect is positive, it could be supportive of the induced innovation hypothesis of Hayami and Ruttan (1985) (Note 15).

The specification employed is the two-way fixed effect model. That is, in addition to the district fixed (or random) effect, the model includes the year dummies for all the available years except the base year, in order to 
control for the yearly change in yield that is not explained by the explanatory variables and the time trend variables, e.g., aggregate macroeconomic and climatic shocks. To check for robustness, we also tried performing regressions (a) without the year dummies but with the time trend, and (b) without the time trend but with the year dummies. The estimated coefficients of the explanatory variables remain largely unchanged in both (a) and (b), indicating that the year dummies mostly capture the random shocks.

In some cases, Heckman's $\rho$ is estimated to be insignificant (i.e., $p>0.10$ ), partly because the district fixed (or random) effect model can mitigate, if not solve, the sample selection bias. The Hausman test is conducted to compare the fixed effect and random effect estimations (Hausman, 1978). Whenever the GLS random effect estimators are diagnosed as inconsistent (i.e., $p<0.10$ ), the fixed effect estimation results are presented (Note 16).

To see the elasticities, the logarithm of the variables are taken whenever applicable, the exceptions being the ratio variables (i.e., irrigation coverage ratio and literacy rate), the time trend variables, the interval-scale variable (temperature in Celsius), and the dummy variables (Stevens, 1946; Rozeboom, 1966).

\subsection{Model Specifications}

How crop yield responds to climate variables needs to be considered. The simplest model is $m=1$, which is expected to capture the linear effects of climate variables. The benefit of this model is that it is easy to observe whether the impacts of climate variables are positive or negative, as well as their changes over time in the presence of the interaction terms with the time trend variables $\left(t\right.$ and $\left.\mathrm{t}^{2}\right)$. However, assuming that there is a yield-maximizing value of climate input, it may be appropriate to include quadratic terms with respect to those climate variables (i.e., $m=2$ ), so as to capture the non-linear yield curves. To check the robustness, regressions with $m=1$ are also performed and the two models are compared.

\subsection{Analytical Framework for Identifying the Changing Impacts}

Once the estimators of the coefficients are found, crop yield is predicted by

$$
\widehat{Y_{i j t}}=\sum_{k=1}^{m} \widehat{\alpha_{0 k i}} C_{j t}^{k}+\sum_{k=1}^{m} \widehat{\alpha_{1 k i}} C_{j t}^{k} \cdot t+\sum_{k=1}^{m} \widehat{\alpha_{2 k i}} C_{j t}^{k} \cdot t^{2}+\widehat{\beta}_{i} C_{j t} \cdot \text { irri } i_{i j t}+\text { others },
$$

Where others includes all the terms independent of the variable $C_{j t}$. Hence, for $m=1$ and 2 respectively, the predicted marginal effect of $C_{j t}$ on yield is expressed as follows:

$$
\widehat{M E_{i j t}}=\frac{\partial \widehat{Y}_{i j t}}{\partial C_{j t}}=\widehat{\alpha_{01 i}}+\widehat{\alpha_{11 i}} \cdot t+\widehat{\alpha_{21 i}} \cdot t^{2}+\widehat{\beta}_{i} \cdot i_{r r i}(\text { for } m=1)
$$

And

$$
\widehat{M E_{i j t}}=\frac{\partial \widehat{Y}_{i j t}}{\partial C_{j t}}=\widehat{\alpha_{01 i}}+\widehat{\alpha_{11 i}} \cdot t+\widehat{\alpha_{11 i}} \cdot t^{2}+2 C_{j t}\left(\widehat{\alpha_{02 i}}+\widehat{\alpha_{12 i}} \cdot t+\widehat{\alpha_{22 i}} \cdot t^{2}\right)+\widehat{\beta}_{i} \cdot i r r i_{i j t}(\text { for } m=2) .
$$

Taking the average over $j$ (districts), the average marginal effect of $C_{t}$ is given by

$$
A v g \cdot \widehat{M E_{i t}}=\widehat{\alpha_{01 i}}+\widehat{\alpha_{11 i}} \cdot t+\widehat{\alpha_{21 i}} \cdot t^{2}+\widehat{\beta}_{i} \cdot \overline{\text { irri }_{i t}}(\text { for } m=1)
$$

And

$$
\left.A v g \cdot \widehat{M E_{i t}}=\widehat{\alpha_{01 i}}+\widehat{\alpha_{11 i}} \cdot t+\widehat{\alpha_{21 i}} \cdot t^{2}+2 \overline{C_{t}}\left(\widehat{\alpha_{02 i}}+\widehat{\alpha_{12 i}} \cdot t+\widehat{\alpha_{22 i}} \cdot t^{2}\right)+\widehat{\beta_{i}} \cdot \overline{i r r i} \text { (for } m=2\right)
$$

for each $t$. By these formulae, the marginal effect of $C t$ or a given explanatory variable on the yield of crop $i$ is predicted for each $t$, and thus, the changing impacts of climate variables can be examined by altering $t$ from 0 to 30. Also, the overall average of the marginal effect of $C$ is given for the respective $m$ by

$$
\frac{1}{31} \sum_{t=0}^{30} A v g \cdot \widehat{M E_{i t}}
$$

\section{Regression Results for Yield Functions}

Table 3a presents the estimation results of the yield equations for wheat and rice, Table $3 \mathrm{~b}$ presents the results for maize, and Table $3 \mathrm{c}$ shows those for sorghum and millet. To keep the tables succinct, the estimated coefficients on the year dummy variables are not presented. By the Hausman test, the GLS random effect estimators are diagnosed as inconsistent in all cases except for the case $m=1$ with maize. Therefore, the fixed effect is adopted in the estimation of the yield equations of all other cases. In the case of $m=1$ with maize, both fixed and random effect estimation results are presented since the diagnosis of the Hausman test is somewhat 
ambiguous $(p=0.06)$. Sample selection bias is diagnosed as statistically significant in the case of rice and maize, and is duly treated, shown by the coefficients on the inverse Mills ratios. In the Results section, summarize the collected data and the analysis performed on those data relevant to the discourse that.

\subsection{Wheat}

According to the case with $m=1$, temperature by itself does not pose a statistically significant effect on wheat yield, whereas the independent effect of rainfall is positive and significant. Yet, computation using Equation 3 reveals that both specifications indicate that the total temperature effect, including the effects via all the interaction terms, is actually significant and negative on average during the period under study. Somewhat unexpectedly, the independent effect of irrigation on wheat yield is insignificant. This would be partly because most wheat fields are irrigated (Singh \& Jain, 2000), so that the marginal effect is not identified and partly because wheat is a dry-season crop (Fujisaka, Harrington, \& Hobbs, 1994) to which irrigation provides water only occasionally. Even so, since irrigation has interactive effects with the climate variables as shown by the coefficients on the climate-irrigation interaction terms, the total effect of irrigation appears to be significant and positive at 0.07 on average during the study period (derived by Equation 3). The quantitative interpretation of this figure is such that when irrigation coverage for wheat fields increases by 10 percentage points, wheat yield rises by 0.7 percent on average, holding other variables constant.

The signs of the climate-irrigation interaction effects indicate that higher irrigation coverage leads to a positive and significant effect of higher temperature, and to a reduced dependence on rainfall. (Note 17) A 10 percentage point increase in irrigation rate reduces rainfall elasticity by 0.012 , indicating that the role of rainfall can be substituted for by the presence of irrigation.

For $m=1$, the coefficients on the time trend variables indicate that the impact of general technological advancement is positive on average. For $m=2$, the same impact seems negative presumably because yield growth over time is sufficiently captured by the interaction between time and the quadratic climate variables.

The most remarkable result is the declining dependence of wheat yield on rainfall over time. The rainfall elasticity of wheat yield is positive and significant $(0.25$ for $m=1$ and 0.29 for $m=2)$ at the beginning of the period under study (i.e., 1972), but it is predicted to decrease over time in both specifications, approaching zero in 1987 (for $m=1$ ) or decreasing to 0.06 in 2002 (for $m=2$ ), as predicted by Equation 1 and Equation 2. It is important to note that this change over time in the impact of rainfall is not inclusive of the influence of the availability of irrigation, since that influence is controlled for by the rainfall-irrigation interaction term. The result thus clearly supports our hypothesis that the rainfall effect is lessened, not augmented, by technological changes over time.

The population density elasticity of wheat yield is $0.11(m=1)$ or $0.12(m=2)$ on average through the study period, which could be supportive of the induced innovation hypothesis.

\subsection{Rice}

Rice is known as a crop that grows well with adequate heat and water, which is confirmed by the positive and significant total effects of temperature, rainfall, and irrigation on average during the study period (predicted by Equation 3), being $0.045(m=1), 0.162(m=1)$ or $0.164(m=2)$, and $2.010(m=2)$, respectively. In other words, a one degree rise in temperature leads to a 4.5 percent increase in yield; the rainfall elasticity of yield is about 0.16 ; and a one percentage point increase in irrigation coverage leads to improving yield by 2.0 percent, holding other variables constant. In contrast to wheat, the independent effect of irrigation on rice yield is also positive and significant in both specifications.

The computation of the changing effects of the climate variables using Equation 1 and Equation 2 indicates that the dependence of rice yield on climate is alleviated over time. For $m=1$, the temperature effect is predicted as 0.086 in 1972, which decreases over time and becomes 0.032 in 2002. The predicted rainfall elasticity is $0.51(\mathrm{~m}$ $=1)$ or $0.42(m=2)$ in 1972, which diminishes over time and approaches zero in the mid 1990s in both specifications. These results support our hypothesis that rice yield has been affected less by climatic conditions over time, probably due to the adoption of improved rice varieties. Again, these changes over time in the impact of climatic variables are net of the influence of irrigation diffusion, since that influence is controlled for by the climate-irrigation interaction terms. Therefore, the critically important finding here is that the dependence of rice yield on climatic conditions is mitigated over time regardless of the availability of irrigation, which can hardly be understood without considering the impact of the adoption of MVs with shorter maturity and other drought-tolerance traits. Also, the negative coefficients on the rainfall-irrigation and the temperature-irrigation interaction terms indicate that irrigation can reduce the impact of climate, to some extent. 
Table 3a. Estimation of Yield Equations for Wheat and Rice, 1972 to 2002

\begin{tabular}{|c|c|c|c|c|}
\hline \multirow{2}{*}{$\begin{array}{l}\text { Dependent Variable: } \\
\text { Ln Yield } \\
\text { Specification }\end{array}$} & \multicolumn{2}{|c|}{ Wheat } & \multicolumn{2}{|c|}{ Rice } \\
\hline & $m=1$ & $m=2$ & $m=1$ & $m=2$ \\
\hline District Effect & FE & FE & FE & FE \\
\hline Temperature & $\begin{array}{l}-0.0016 \\
(0.0192)\end{array}$ & $\begin{array}{c}-0.6218^{* *} \\
(0.2767)\end{array}$ & $\begin{array}{c}0.1091^{* * * *} \\
(0.0249)\end{array}$ & $\begin{array}{l}-0.1940 \\
(0.3279)\end{array}$ \\
\hline$(\text { Temperature })^{2}$ & & $\begin{array}{c}0.0124 * * \\
(0.0055)\end{array}$ & & $\begin{array}{c}0.0057 \\
(0.0064)\end{array}$ \\
\hline Temperature $\times \mathrm{t}$ & $\begin{array}{c}-0.0054 * * * \\
(0.0013)\end{array}$ & $\begin{array}{c}0.0908 * * * \\
(0.0206)\end{array}$ & $\begin{array}{c}-0.0044 * * * \\
(0.0016)\end{array}$ & $\begin{array}{c}0.0246 \\
(0.0252)\end{array}$ \\
\hline$(\text { Temperature })^{2} \times t$ & & $\begin{array}{c}-0.0019 * * * \\
(0.0004)\end{array}$ & & $\begin{array}{l}-0.0006 \\
(0.0005)\end{array}$ \\
\hline Temperature $\times \mathrm{t}^{2}$ & $\begin{array}{c}0.0001 * * * \\
(0.0000)\end{array}$ & $\begin{array}{c}-0.0013 * * * \\
(0.0005)\end{array}$ & $\begin{array}{c}0.0001^{* *} \\
(0.0000)\end{array}$ & $\begin{array}{l}-0.0006 \\
(0.0006)\end{array}$ \\
\hline$(\text { Temperature })^{2} \times t^{2}$ & & $\begin{array}{c}0.0000^{* * * *} \\
(0.0000)\end{array}$ & & $\begin{array}{c}0.0000 \\
(0.0000)\end{array}$ \\
\hline Temperature $\times$ Irrigation Coverage & $\begin{array}{c}0.0361 * * * \\
(0.0145)\end{array}$ & $\begin{array}{c}0.0238 \\
(0.0152)\end{array}$ & $\begin{array}{c}-0.0584 * * * \\
(0.0237)\end{array}$ & $\begin{array}{l}-0.0508^{* *} \\
(0.0235)\end{array}$ \\
\hline Ln Rainfall & $\begin{array}{c}0.3149 * * * \\
(0.0338)\end{array}$ & $\begin{array}{c}-1.4112 * * * \\
(0.2832)\end{array}$ & $\begin{array}{c}0.5713 * * * \\
(0.0395)\end{array}$ & $\begin{array}{c}5.6675 * * * \\
(0.4132)\end{array}$ \\
\hline$(\text { Ln Rainfall })^{2}$ & & $\begin{array}{c}0.1255^{* * * *} \\
(0.0207)\end{array}$ & & $\begin{array}{c}-0.3717 * * * \\
(0.0303)\end{array}$ \\
\hline Ln Rainfall $\times \mathrm{t}$ & $\begin{array}{c}-0.0173 * * * \\
(0.0029)\end{array}$ & $\begin{array}{c}0.1110 * * * \\
(0.0278)\end{array}$ & $\begin{array}{c}-0.0223 * * * \\
(0.0040)\end{array}$ & $\begin{array}{c}-0.5037 * * * \\
(0.0431)\end{array}$ \\
\hline$(\text { Ln Rainfall })^{2} \times t$ & & $\begin{array}{c}-0.0090 * * * \\
(0.0021)\end{array}$ & & $\begin{array}{c}0.0349 * * * \\
(0.0032)\end{array}$ \\
\hline Ln Rainfall $\times \mathrm{t}^{2}$ & $\begin{array}{l}0.0004 * * * \\
(0.0001)\end{array}$ & $\begin{array}{c}-0.0018 * * * \\
(0.0007)\end{array}$ & $\begin{array}{c}0.0001 \\
(0.0001)\end{array}$ & $\begin{array}{c}0.0098 * * * \\
(0.0011)\end{array}$ \\
\hline$(\text { Ln Rainfall })^{2} \times t^{2}$ & & $\begin{array}{c}0.0001 * * * \\
(0.0001)\end{array}$ & & $\begin{array}{c}-0.0007 * * * \\
(0.0001)\end{array}$ \\
\hline Ln Rainfall $\times$ Irrigation Coverage & $\begin{array}{c}-0.1228 * * * \\
(0.0289)\end{array}$ & $\begin{array}{c}-0.0739 * * * \\
(0.0298)\end{array}$ & $\begin{array}{c}-0.1509 * * * \\
(0.0262)\end{array}$ & $\begin{array}{c}-0.1272 * * * \\
(0.0260)\end{array}$ \\
\hline Irrigation Coverage for Each Crop & $\begin{array}{c}0.1366 \\
(0.4338)\end{array}$ & $\begin{array}{c}0.0816 \\
(0.4530)\end{array}$ & $\begin{array}{c}2.8437 * * * \\
(0.6575)\end{array}$ & $\begin{array}{c}2.5425 * * * \\
(0.6507)\end{array}$ \\
\hline Irrigation Coverage $\times \mathrm{t}$ & $\begin{array}{l}-0.0001 \\
(0.0060)\end{array}$ & $\begin{array}{c}0.0076 \\
(0.0060)\end{array}$ & $\begin{array}{l}0.0155^{* * *} * \\
(0.0056)\end{array}$ & $\begin{array}{l}0.0110 * * \\
(0.0057)\end{array}$ \\
\hline Irrigation Coverage $\times \mathrm{t}^{2}$ & $\begin{array}{l}-0.0001 \\
(0.0002)\end{array}$ & $\begin{array}{l}-0.0004 * * \\
(0.0002)\end{array}$ & $\begin{array}{c}-0.0006 * * * \\
(0.0002)\end{array}$ & $\begin{array}{l}-0.0004 * * \\
(0.0002)\end{array}$ \\
\hline Literacy Rate & $\begin{array}{c}0.2318 \\
(0.2294)\end{array}$ & $\begin{array}{l}-0.0914 \\
(0.2332)\end{array}$ & $\begin{array}{c}0.0645 \\
(0.3017)\end{array}$ & $\begin{array}{c}0.2010 \\
(0.2993)\end{array}$ \\
\hline Literacy Rate $\times$ t & $\begin{array}{l}-0.0290 * \\
(0.0158)\end{array}$ & $\begin{array}{l}-0.0013 \\
(0.0160)\end{array}$ & $\begin{array}{l}-0.0258 \\
(0.0204)\end{array}$ & $\begin{array}{l}-0.0399 * * \\
(0.0203)\end{array}$ \\
\hline Literacy Rate $\times \mathrm{t}^{2}$ & $\begin{array}{l}0.0006 \\
(0.0005)\end{array}$ & $\begin{array}{l}-0.0001 \\
(0.0005)\end{array}$ & $\begin{array}{l}-0.0002 \\
(0.0006)\end{array}$ & $\begin{array}{c}0.0000 \\
(0.0006)\end{array}$ \\
\hline Ln Population Density & $\begin{array}{l}0.1067 * * \\
(0.0437)\end{array}$ & $\begin{array}{c}0.1198 * * * \\
(0.0434)\end{array}$ & $\begin{array}{c}0.1497 * * * \\
(0.0457)\end{array}$ & $\begin{array}{c}0.1284 * * * \\
(0.0451)\end{array}$ \\
\hline Ln Population Density $\times \mathrm{t}$ & $\begin{array}{l}-0.0023 \\
(0.0023)\end{array}$ & $\begin{array}{l}-0.0031 \\
(0.0023)\end{array}$ & $\begin{array}{l}-0.0019 \\
(0.0028)\end{array}$ & $\begin{array}{l}-0.0016 \\
(0.0028)\end{array}$ \\
\hline Ln Population Density $\times \mathrm{t}^{2}$ & $\begin{array}{l}0.0001^{*} \\
(0.0001)\end{array}$ & $\begin{array}{c}0.0001 \\
(0.0001)\end{array}$ & $\begin{array}{c}0.0001 \\
(0.0001)\end{array}$ & $\begin{array}{c}0.0001 \\
(0.0001)\end{array}$ \\
\hline Inverse Mills Ratio & $\begin{array}{l}-0.0765 \\
(0.0640)\end{array}$ & $\begin{array}{l}-0.0700 \\
(0.0636)\end{array}$ & $\begin{array}{l}0.4889 * * * \\
(0.0852)\end{array}$ & $\begin{array}{l}0.3826 * * * \\
(0.0863)\end{array}$ \\
\hline $\mathrm{t}$ & $\begin{array}{c}0.3142 * * * \\
(0.0401)\end{array}$ & $\begin{array}{c}-1.3737 * * * \\
(0.2725)\end{array}$ & $\begin{array}{c}0.2550 * * * \\
(0.0505)\end{array}$ & $\begin{array}{l}1.5449 * * * \\
(0.3522)\end{array}$ \\
\hline$t^{2}$ & $\begin{array}{l}-0.0065 * * * \\
(0.0012)\end{array}$ & $\begin{array}{l}0.0201 * * * \\
(0.0065)\end{array}$ & $\begin{array}{l}-0.0023 \\
(0.0015)\end{array}$ & $\begin{array}{l}-0.0276 * * * \\
(0.0083)\end{array}$ \\
\hline Constant Term & $\begin{array}{c}3.9938 * * * \\
(0.5848)\end{array}$ & $\begin{array}{c}17.7013 * * * \\
(3.6808)\end{array}$ & $\begin{array}{c}-0.9224 * * \\
(0.7262) \\
\end{array}$ & $\begin{array}{c}-14.2264 * * * \\
(4.4862) \\
\end{array}$ \\
\hline Number of Observations & & & & \\
\hline R-squared: Overall & 0.3175 & 0.1511 & 0.4169 & 0.4304 \\
\hline Hausman Test & & & & \\
\hline $\begin{array}{l}\chi^{2} \text { statistics (degrees of freedom) } \\
\text { Prob }>\chi^{L}\end{array}$ & $\begin{array}{c}764.24(43) \\
0.0000\end{array}$ & $\begin{array}{c}-597.01(46) \\
n / a\end{array}$ & $\begin{array}{c}100.54(43) \\
0.0000\end{array}$ & $\begin{array}{c}131.39(46) \\
0.0000\end{array}$ \\
\hline
\end{tabular}

$* * *, * *$, and $*$ indicate 1 percent, 5 percent, and 10 percent statistical significance levels, respectively.

Standard errors are in the parentheses.

Note that the logarithm of temperature is mathematically inappropriate unless it is a Kelvin measure. See also section 3.3 . 
Another highly interesting point is that the predicted total irrigation effect, including the interactive effect with climate, increases in the early phase, from 1.96 (percent per percentage point) in 1972 to 2.06 in 1985, but then decreases in the late phase and becomes 1.89 in 2002, according to the specification $m=2$. For $m=1$ also, the predicted irrigation effect hits its peak in 1985. These results clearly suggest that early generations of rice technology require more irrigation than do recent ones, which is consistent with the descriptive analysis of MV adoption by Janaiah, Hossain and Otsuka (2006) and Byerlee (1996). Also, it is confirmed that irrigation works to reduce the impact of temperature and rainfall. A 10 percentage point increase in irrigation rate reduces rainfall elasticity by 0.015 .

The induced innovation hypothesis may be supported, to a greater degree than for wheat, by the significant and positive population density elasticity ranging from 0.13 to 0.15 . The coefficient on the time trend variable indicates that the impact of general technological advancement seems positive and significant throughout the study period, though the magnitude varies by specification.

\subsection{Maize}

According to the estimation case $m=1$ (see Table $3 \mathrm{~b}$ ), the total temperature effect was negative and significant at the beginning of the study period in both fixed effect (FE) and random effect (RE) specifications, where a one degree rise in temperature resulted in a three to five percent drop in maize yield. However, it turns out from Equation 1 to Equation 3 that, on average and for most of the study period, the temperature effect on maize yield was positive and significant. Moreover, this positive marginal effect augments over time at first, hitting 0.033 (FE) or 0.049 (RE) in 1992, and then declines over time, becoming 0.014 (FE) or 0.028 (RE) in 2002. These results suggest that although the early generations of maize MVs are increasingly dependent on temperature, the dependence is mitigated after 1992 with the diffusion of the newer generations of MVs, which is consistent with the report by Gollin (2006).

The unique result for maize may be the total rainfall effect being much less significant than for the other crops, with an average elasticity of 0.101 (in RE for $m=1$ ), which does not evolve over time. The effects of irrigation and its interactions with the time trend variables are all statistically insignificant. Also, the substitution relationship between rainfall and irrigation is weak. This absence of both rainfall effects and irrigation effects throughout the study period indicates that maize, whether TVs or MVs, is likely to be a drought-tolerant crop that can cope well with the lack of a stable water supply.

All three specifications similarly indicate that for a one percentage point increase in literacy rate, maize yield rises by 1.3-1.5 percent in 1972, and this marginal effect decreases over time. The population density elasticity of yield turns out to be negative at -0.23 to -0.22 in 1972 , but it increases over time to become positive at 0.03 to 0.15 in 2002.

Somewhat unexpectedly, the coefficient on the time trend variable is negative, which indicates that the positive impacts of the adoption of improved maize technology are well captured, for the most part, by the changing coefficients on the explanatory variables over time. 
Table 3b. Estimation of Yield Equations for Maize, 1972 to 2002

\begin{tabular}{|c|c|c|c|}
\hline \multirow{3}{*}{$\begin{array}{l}\text { Dependent Variable: } \\
\text { Ln Yield } \\
\text { Specification } \\
\text { District Effect } \\
\end{array}$} & \multicolumn{3}{|c|}{ Maize } \\
\hline & \multicolumn{2}{|c|}{$m=1$} & \multirow{2}{*}{$\begin{array}{c}m=2 \\
\mathrm{FE}\end{array}$} \\
\hline & FE & $\mathrm{RE}$ & \\
\hline Temperature & $\begin{array}{l}-0.0600 * * \\
(0.0263)\end{array}$ & $\begin{array}{l}-0.0288^{*} \\
(0.0168)\end{array}$ & $\begin{array}{c}0.5036 \\
(0.4432)\end{array}$ \\
\hline$(\text { Temperature })^{2}$ & & & $\begin{array}{l}-0.0109 \\
(0.0087)\end{array}$ \\
\hline Temperature $\times \mathrm{t}$ & $\begin{array}{c}0.0080 * * * \\
(0.0020)\end{array}$ & $\begin{array}{c}0.0079 * * * \\
(0.0019)\end{array}$ & $\begin{array}{c}0.0303 \\
(0.0290)\end{array}$ \\
\hline$(\text { Temperature })^{2} \times t$ & & & $\begin{array}{l}-0.0004 \\
(0.0006)\end{array}$ \\
\hline Temperature $\times \mathrm{t}^{2}$ & $\begin{array}{c}-0.0002 * * * \\
(0.0001)\end{array}$ & $\begin{array}{c}-0.0002 * * * \\
(0.0001)\end{array}$ & $\begin{array}{l}-0.0013^{*} \\
(0.0007)\end{array}$ \\
\hline$(\text { Temperature })^{2} \times \mathrm{t}^{2}$ & & & $\begin{array}{l}0.0000 \\
0.0000\end{array}$ \\
\hline Temperature $\times$ Irrigation Coverage & $\begin{array}{l}0.0405^{*} \\
(0.0228)\end{array}$ & $\begin{array}{c}0.0165 \\
(0.0165)\end{array}$ & $\begin{array}{c}0.0491 * * \\
(0.0235)\end{array}$ \\
\hline Ln Rainfall & $\begin{array}{c}0.0610 \\
(0.0425)\end{array}$ & $\begin{array}{c}0.0881^{* *} \\
(0.0420)\end{array}$ & $\begin{array}{c}0.6292 \\
(0.4189)\end{array}$ \\
\hline$(\text { Ln Rainfall })^{2}$ & & & $\begin{array}{l}-0.0431 \\
(0.0311)\end{array}$ \\
\hline Ln Rainfall $\times \mathrm{t}$ & $\begin{array}{l}-0.0024 \\
(0.0044)\end{array}$ & $\begin{array}{l}-0.0032 \\
(0.0044)\end{array}$ & $\begin{array}{l}-0.0332 \\
(0.0430)\end{array}$ \\
\hline$(\text { Ln Rainfall })^{2} \times \mathrm{t}$ & & & $\begin{array}{c}0.0022 \\
(0.0033)\end{array}$ \\
\hline Ln Rainfall $\times \mathrm{t}^{2}$ & $\begin{array}{c}0.0000 \\
(0.0001)\end{array}$ & $\begin{array}{c}0.0000 \\
(0.0001)\end{array}$ & $\begin{array}{c}0.0006 \\
(0.0010)\end{array}$ \\
\hline$(\text { Ln Rainfall })^{2} \times t^{2}$ & & & $\begin{array}{c}0.0000 \\
(0.0001)\end{array}$ \\
\hline Ln Rainfall $\times$ Irrigation Coverage & $\begin{array}{c}0.0051 \\
(0.0275)\end{array}$ & $\begin{array}{l}0.0431 * \\
(0.0261)\end{array}$ & $\begin{array}{l}-0.0175 \\
(0.0287)\end{array}$ \\
\hline Irrigation Coverage for Each Crop & $\begin{array}{l}-0.9642 \\
(0.6431)\end{array}$ & $\begin{array}{l}-0.4740 \\
(0.4784)\end{array}$ & $\begin{array}{l}-1.0266 \\
(0.6620)\end{array}$ \\
\hline Irrigation Coverage $\times \mathrm{t}$ & $\begin{array}{c}0.0030 \\
(0.0076)\end{array}$ & $\begin{array}{c}0.0040 \\
(0.0076)\end{array}$ & $\begin{array}{c}0.0026 \\
(0.0077)\end{array}$ \\
\hline Irrigation Coverage $\times t^{2}$ & $\begin{array}{l}-0.0003 \\
(0.0002)\end{array}$ & $\begin{array}{l}-0.0001 \\
(0.0002)\end{array}$ & $\begin{array}{l}-0.0003 \\
(0.0002)\end{array}$ \\
\hline Literacy Rate & $\begin{array}{c}1.3287 * * * \\
(0.3779)\end{array}$ & $\begin{array}{c}1.5071 * * * \\
(0.2655)\end{array}$ & $\begin{array}{c}1.2846^{* * * *} \\
(0.3820)\end{array}$ \\
\hline Literacy Rate $\times \mathrm{t}$ & $\begin{array}{c}-0.0544 * * \\
(0.0248)\end{array}$ & $\begin{array}{c}-0.0671 * * * \\
(0.0245)\end{array}$ & $\begin{array}{c}-0.0547 * * \\
(0.0250)\end{array}$ \\
\hline Literacy Rate $\times \mathrm{t}^{2}$ & $\begin{array}{l}-0.0001 \\
(0.0008)\end{array}$ & $\begin{array}{l}0.0005 \\
(0.0007)\end{array}$ & $\begin{array}{l}-0.0001 \\
(0.0008)\end{array}$ \\
\hline Ln Population Density & $\begin{array}{c}-0.2211^{* * *} \\
(0.0614)\end{array}$ & $\begin{array}{c}-0.2251 * * * \\
(0.0315)\end{array}$ & $\begin{array}{c}-0.2277 * * * \\
(0.0617)\end{array}$ \\
\hline Ln Population Density $\times \mathrm{t}$ & $\begin{array}{c}0.0124 * * * \\
(0.0036)\end{array}$ & $\begin{array}{c}0.0144 * * * \\
(0.0036)\end{array}$ & $\begin{array}{c}0.0123 * * * \\
(0.0037)\end{array}$ \\
\hline Ln Population Density $\times \mathrm{t}^{2}$ & $\begin{array}{l}-0.0001 \\
(0.0001)\end{array}$ & $\begin{array}{c}-0.0002 * * \\
(0.0001)\end{array}$ & $\begin{array}{l}-0.0001 \\
(0.0001)\end{array}$ \\
\hline Inverse Mills Ratio & $\begin{array}{c}0.7461^{* *} \\
(0.3127)\end{array}$ & $\begin{array}{c}0.6788^{* *} \\
(0.2915)\end{array}$ & $\begin{array}{c}0.8935^{* * *} * \\
(0.3176)\end{array}$ \\
\hline $\mathrm{t}$ & $\begin{array}{c}-0.2679 * * \\
(0.1251)\end{array}$ & $\begin{array}{c}-0.3343 * * * \\
(0.1229)\end{array}$ & $\begin{array}{l}-0.4345 \\
(0.4048)\end{array}$ \\
\hline$t^{2}$ & $\begin{array}{l}-0.1114 \\
(0.1095)\end{array}$ & $\begin{array}{l}-0.0480 \\
(0.1072)\end{array}$ & $\begin{array}{l}-0.1026 \\
(0.1102)\end{array}$ \\
\hline Constant Term & $\begin{array}{c}8.8777 * * * \\
(0.8114)\end{array}$ & $\begin{array}{c}7.7295 * * * \\
(0.5758)\end{array}$ & $\begin{array}{l}-0.1936 \\
(5.8801)\end{array}$ \\
\hline Number of Observations & & 5317 & \\
\hline R-squared: Overall & 0.2250 & 0.2855 & 0.1890 \\
\hline Hausman Test & & & \\
\hline $\begin{array}{l}\chi^{2} \text { statistics (degrees of freedom) } \\
\text { Prob }>\chi^{2}\end{array}$ & & & $\begin{array}{c}132.02(10) \\
0.0000\end{array}$ \\
\hline
\end{tabular}

$* * *, * *$, and * indicate 1 percent, 5 percent, and 10 percent statistical significance levels, respectively.

Standard errors are in the parentheses.

Note that the logarithm of temperature is mathematically inappropriate unless it is a Kelvin measure. See also section 3.3 . 


\subsection{Sorghum}

By Equation 3, a positive and significant total effect of temperature is found in both specifications, indicating that sorghum may be a heat-preferring crop (see Table 3c). For $m=1$, Equation 1 indicates that the dependence of sorghum yield on temperature decreases over time from 5.5 in 1972 to 4.7 in 2002 . Also, for $m=2$, Equation 2 reveals that temperature dependence decreases over time if we disregard the nearly insignificant coefficient on the temperature squared-time trend squared interaction term.

Particularly noteworthy is the decreasing marginal effect of rainfall, which again suggests the declining impacts of rainfall on crop yield. The total rainfall effect is positive and significant with the elasticity being $0.43(m=1)$ or $0.34(m=2)$ in 1972, which decreases over time and becomes $0.11(m=1)$ or $0.17(m=2)$ in 2002. Although more concrete evidence is awaited, it may be the case that a major effect of the improved traits of sorghum MVs is a reduction in downward yield risk associated with drought (Note 18).

The total impact of irrigation is $0.55(m=1)$ or $1.14(m=2)$ in 1972 , which seems to decrease over time and becomes $0.36(m=1)$ or $0.96(m=2)$ in 2002. The positive and significant impact of irrigation on sorghum yield is not surprising, as it is in line with the findings by Janaiah et al. (2005) on the complementary irrigation effect with MVs on the yields of course cereals (maize, sorghum, and millet) in India. After all, as for sorghum, the impacts of temperature, rainfall and irrigation have all declined or even disappeared over the course of time. In addition, irrigation seems to have a substitution effect for climate variables, which is shown by the negative and significant coefficients on the interaction terms, indicating that when irrigation availability increases, the impact of temperature and rainfall on sorghum yield decreases.

Similar to wheat and rice, the induced innovation hypothesis seems to apply to sorghum farming throughout the study period, which is shown by the population density elasticity being $0.15(m=1)$ or $0.11(m=2$; at 14 percent significance level).

\subsection{Millet}

By Equation 1 and Equation 2, the predicted total temperature effect on millet yield is $0.059(\mathrm{~m}=1)$ or $0.052(\mathrm{~m}$ $=2$ ) in 1972, which is similar to that for sorghum, indicating that millet is also a heat-dependent crop. Over time, this total temperature effect declines and becomes $0.042(m=1)$ or $0.016(m=2)$ in 2002. (Note 19) The total rainfall effect in 1972 is positive and significant with the elasticity being $0.26(m=1)$ or $0.20(m=2)$. The difference from the case of sorghum is that it is not clear whether this rainfall effect exhibits a decrease over time, since the results from the two specifications are not robust.

Although the independent effect of irrigation appears positive and significant, the total irrigation effect, including the effect through the interaction with temperature, is unclear as the two specifications $(m=1$ and 2$)$ indicate negative and positive effects, respectively (Note 20).

As with sorghum, irrigation seems to have a substitution effect for temperature, which is shown by the negative and significant coefficient on the interaction term in both specifications, indicating that when irrigation availability increases, the dependence of millet yield on temperature decreases. Lastly, the predicted population density elasticity is insignificant in 1972 but increases over time, becoming $0.084(m=1)$ or $0.075(m=2)$ in 2002. 
Table 3c. Estimation of Yield Equations for Sorghum and Millet, 1972 to 2002

\begin{tabular}{|c|c|c|c|c|}
\hline \multirow{2}{*}{$\begin{array}{l}\text { Dependent Variable: } \\
\text { Ln Yield } \\
\text { Specification }\end{array}$} & \multicolumn{2}{|c|}{ Sorghum } & \multicolumn{2}{|c|}{ Millet } \\
\hline & $m=1$ & $m=2$ & $m=1$ & $m=2$ \\
\hline District Effect & $\mathrm{FE}$ & $\mathrm{FE}$ & $\mathrm{FE}$ & FE \\
\hline Temperature & $\begin{array}{l}0.0640 * * \\
(0.0328)\end{array}$ & $\begin{array}{c}-2.2063^{* * *} \\
(0.5889)\end{array}$ & $\begin{array}{l}0.0659 * * \\
(0.0316)\end{array}$ & $\begin{array}{l}1.1560^{* *} \\
(0.5539)\end{array}$ \\
\hline$(\text { Temperature })^{2}$ & & $\begin{array}{c}0.0444 * * * \\
(0.0115)\end{array}$ & & $\begin{array}{c}-0.0213 * * \\
(0.0108)\end{array}$ \\
\hline Temperature $\times \mathrm{t}$ & $\begin{array}{l}-0.0025 \\
(0.0025)\end{array}$ & $\begin{array}{c}0.1404 * * * \\
(0.0497)\end{array}$ & $\begin{array}{c}0.0029 \\
(0.0024)\end{array}$ & $\begin{array}{l}-0.0128 \\
(0.0476)\end{array}$ \\
\hline$(\text { Temperature })^{2} \times t$ & & $\begin{array}{c}-0.0028 * * * \\
(0.0010)\end{array}$ & & $\begin{array}{c}0.0003 \\
(0.0009)\end{array}$ \\
\hline Temperature $\times \mathrm{t}^{2}$ & $\begin{array}{c}0.0001 \\
(0.0001)\end{array}$ & $\begin{array}{l}-0.0026 \\
(0.0017)\end{array}$ & $\begin{array}{l}-0.0001 \\
(0.0001)\end{array}$ & $\begin{array}{c}0.0008 \\
(0.0016)\end{array}$ \\
\hline$(\text { Temperature })^{2} \times \mathrm{t}^{2}$ & & $\begin{array}{l}0.0001^{*} \\
(0.0000)\end{array}$ & & $\begin{array}{c}0.0000 \\
(0.0000)\end{array}$ \\
\hline Temperature $\times$ Irrigation Coverage & $\begin{array}{c}-0.1147 * * \\
(0.0547)\end{array}$ & $\begin{array}{l}-0.0922 * \\
(0.0546)\end{array}$ & $\begin{array}{c}-0.1287 * * * \\
(0.0506)\end{array}$ & $\begin{array}{c}-0.1217 * * \\
(0.0513)\end{array}$ \\
\hline Ln Rainfall & $\begin{array}{c}0.4167 * * * \\
(0.0494)\end{array}$ & $\begin{array}{c}3.1069 * * * \\
(0.4942)\end{array}$ & $\begin{array}{c}0.2581 * * * \\
(0.0484)\end{array}$ & $\begin{array}{c}2.7592 * * * \\
(0.4902)\end{array}$ \\
\hline$(\text { Ln Rainfall })^{2}$ & & $\begin{array}{c}-0.2021 * * * \\
(0.0370)\end{array}$ & & $\begin{array}{c}-0.1878 * * * \\
(0.0368)\end{array}$ \\
\hline Ln Rainfall $\times \mathrm{t}$ & $\begin{array}{c}-0.0288^{* * *} \\
(0.0052)\end{array}$ & $\begin{array}{c}-0.3099 * * * \\
(0.0509)\end{array}$ & $\begin{array}{l}-0.0021 \\
(0.0051)\end{array}$ & $\begin{array}{c}-0.2408 * * * \\
(0.0509)\end{array}$ \\
\hline$(\text { Ln Rainfall })^{2} \times \mathrm{t}$ & & $\begin{array}{c}0.0216^{* * * *} \\
(0.0039)\end{array}$ & & $\begin{array}{c}0.0180^{* * *} \\
(0.0040)\end{array}$ \\
\hline Ln Rainfall $\times \mathrm{t}^{2}$ & $\begin{array}{l}0.0006^{* * * *} \\
(0.0001)\end{array}$ & $\begin{array}{c}0.0071 * * * \\
(0.0012)\end{array}$ & $\begin{array}{l}-0.0002 \\
(0.0001)\end{array}$ & $\begin{array}{c}0.0049 * * * \\
(0.0012)\end{array}$ \\
\hline$(\text { Ln Rainfall })^{2} \times t^{2}$ & & $\begin{array}{c}-0.0005 * * * \\
(0.0001)\end{array}$ & & $\begin{array}{c}-0.0004 * * * \\
(0.0001)\end{array}$ \\
\hline Ln Rainfall $\times$ Irrigation Coverage & $\begin{array}{c}0.1538 * * * \\
(0.0548)\end{array}$ & $\begin{array}{c}0.1558 * * * \\
(0.0546)\end{array}$ & $\begin{array}{c}0.0649 \\
(0.0697)\end{array}$ & $\begin{array}{c}0.0458 \\
(0.0698)\end{array}$ \\
\hline Irrigation Coverage for Each Crop & $\begin{array}{l}2.4500^{*} \\
(1.4449)\end{array}$ & $\begin{array}{l}1.9556 \\
(1.4422)\end{array}$ & $\begin{array}{c}3.2677 * * * \\
(1.3315)\end{array}$ & $\begin{array}{l}3.2333 * * \\
(1.3529)\end{array}$ \\
\hline Irrigation Coverage $\times \mathrm{t}$ & $\begin{array}{c}-0.0636^{* * *} \\
(0.0207)\end{array}$ & $\begin{array}{c}-0.0725 * * * \\
(0.0207)\end{array}$ & $\begin{array}{l}-0.0221 \\
(0.0153)\end{array}$ & $\begin{array}{l}-0.0231 \\
(0.0155)\end{array}$ \\
\hline Irrigation Coverage $\times \mathrm{t}^{2}$ & $\begin{array}{c}0.0020 * * * \\
(0.0006)\end{array}$ & $\begin{array}{c}0.0021 * * * \\
(0.0006)\end{array}$ & $\begin{array}{c}0.0004 \\
(0.0005)\end{array}$ & $\begin{array}{c}0.0004 \\
(0.0005)\end{array}$ \\
\hline Literacy Rate & $\begin{array}{l}-0.5039 \\
(0.4283)\end{array}$ & $\begin{array}{l}-0.6700 \\
(0.4314)\end{array}$ & $\begin{array}{c}-1.2734 * * * \\
(0.4194)\end{array}$ & $\begin{array}{c}-1.2427 * * * \\
(0.4234)\end{array}$ \\
\hline Literacy Rate $\times \mathrm{t}$ & $\begin{array}{c}0.0498 \\
(0.0311)\end{array}$ & $\begin{array}{l}0.0561 * \\
(0.0314)\end{array}$ & $\begin{array}{c}0.0834 * * * \\
(0.0297)\end{array}$ & $\begin{array}{c}0.0749 * * * \\
(0.0300)\end{array}$ \\
\hline Literacy Rate $\times t^{2}$ & $\begin{array}{l}-0.0011 \\
(0.0010)\end{array}$ & $\begin{array}{l}-0.0012 \\
(0.0010)\end{array}$ & $\begin{array}{l}-0.0015^{*} \\
(0.0009)\end{array}$ & $\begin{array}{l}-0.0013 \\
(0.0010)\end{array}$ \\
\hline Ln Population Density & $\begin{array}{l}0.1501 * * \\
(0.0744)\end{array}$ & $\begin{array}{c}0.1137 \\
(0.0744)\end{array}$ & $\begin{array}{c}0.1096 \\
(0.0747)\end{array}$ & $\begin{array}{c}0.0724 \\
(0.0751)\end{array}$ \\
\hline Ln Population Density $\times \mathrm{t}$ & $\begin{array}{c}0.0004 \\
(0.0046)\end{array}$ & $\begin{array}{c}0.0030 \\
(0.0046)\end{array}$ & $\begin{array}{l}0.0088^{* *} \\
(0.0045)\end{array}$ & $\begin{array}{c}0.0115 * * * \\
(0.0045)\end{array}$ \\
\hline Ln Population Density $\times \mathrm{t}^{2}$ & $\begin{array}{c}0.0000 \\
(0.0002)\end{array}$ & $\begin{array}{l}-0.0001 \\
(0.0002)\end{array}$ & $\begin{array}{l}-0.0002^{*} \\
(0.0001)\end{array}$ & $\begin{array}{c}-0.0003 * * \\
(0.0001)\end{array}$ \\
\hline Inverse Mills Ratio & $\begin{array}{l}-0.0588 \\
(0.0657)\end{array}$ & $\begin{array}{l}-0.0282 \\
(0.0666)\end{array}$ & $\begin{array}{l}-0.0578 \\
(0.0673)\end{array}$ & $\begin{array}{l}-0.0644 \\
(0.0680)\end{array}$ \\
\hline $\mathrm{t}$ & $\begin{array}{c}0.2330 * * * \\
(0.0752)\end{array}$ & $\begin{array}{l}-0.6610 \\
(0.6515)\end{array}$ & $\begin{array}{c}-0.1620 * * \\
(0.0708)\end{array}$ & $\begin{array}{c}0.7986 \\
(0.6239)\end{array}$ \\
\hline$t^{2}$ & $\begin{array}{c}-0.0050 * * \\
(0.0025)\end{array}$ & $\begin{array}{c}0.0077 \\
(0.0215)\end{array}$ & $\begin{array}{c}0.0070 * * * \\
(0.0024)\end{array}$ & $\begin{array}{l}-0.0212 \\
(0.0207)\end{array}$ \\
\hline Constant Term & $\begin{array}{l}1.0884 \\
(0.9656)\end{array}$ & $\begin{array}{l}21.3557 \\
(7.7821)\end{array}$ & $\begin{array}{c}2.7625 * * * \\
(0.9298)\end{array}$ & $\begin{array}{l}-19.2814 \\
(7.3180)\end{array}$ \\
\hline Number of Observations & & & & \\
\hline R-squared: Overall & 0.1982 & 0.2050 & 0.2759 & 0.2295 \\
\hline Hausman Test & & & & \\
\hline $\begin{array}{l}\chi^{2} \text { statistics (degrees of freedom) } \\
\text { Prob }>\chi^{L}\end{array}$ & $\begin{array}{c}87.72(42) \\
0.0000\end{array}$ & $\begin{array}{l}170.34(45) \\
0.0000\end{array}$ & $\begin{array}{c}-133.50(43) \\
\mathrm{n} / \mathrm{a}\end{array}$ & $\begin{array}{c}-14.31(45) \\
n / a\end{array}$ \\
\hline
\end{tabular}

$* * *, * *$, and $*$ indicate 1 percent, 5 percent, and 10 percent statistical significance levels, respectively.

Standard errors are in the parentheses.

Note that the logarithm of temperature is mathematically inappropriate unless it is a Kelvin measure. See also section 3.3 . 


\section{Is It Really Technology That Mattered?}

\subsection{Introduction of the Issue}

The results from section 4 strongly indicate that the impact of climatic factors on crop yields have declined over time for all five crops in one way or another, even after the contribution of irrigation effects is controlled for. Although it seems reasonable to assume that technological progress represented by the adoption of high-yielding MVs and other improved production practices has contributed to these changes over time, it is not directly proven by the regression analyses since the time trend variables could reflect the effects of a variety of other factors. The difficulty is that the data for technology variables, such as MV adoption rate, are unavailable at the district level. Moreover, even if those variables were available, their use might suffer from a problem of endogeneity bias, which would not be easy to correct for, given the absence of suitable instruments. Even so, Figure 5 is highly suggestive of the monotonically positive correlation between the time trend and MV adoption rates for the differing crops, supporting our use of the time trend variable as an indicator of technology diffusion.

One attempt to obtain more direct evidence of the impact of technology is to use irrigation as a proxy for the compound effects of irrigation and MVs in the early years of the GR, because MVs were adopted primarily in irrigated areas in the early phase of the GR. Thus, for validation, we propose to investigate the relationship between the MV adoption rate and the irrigation rate using state-level data. Figure 6 shows the changes over time in correlation coefficient between the state-level MV adoption rate and the state-level irrigation rate by crop. In the early GR period (1974 to 1988), the correlation coefficients are high for wheat, rice, and maize at 0.76, 0.79, and 0.62 respectively, while they are only $0.38,0.35$, and 0.46 in the subsequent period (1989 to 2002). In fact, such a trend is consistent with the preceding studies by Janaiah et al. (2006), Gollin (2006), and Byerlee (1996), all of which point out that the MVs released in the earlier period were high-yielding only under favorable production environments, whereas subsequent generations of MVs possess traits suitable for a variety of agro-climates. Given these changing correlation coefficients, we attempt to find out the impact of technology on the climate effects by regarding the district-level irrigation variable as a district-level technology indicator, which is expected to capture the compound effects of irrigation and MV technology only in the early stage of the GR for wheat, rice, and maize.

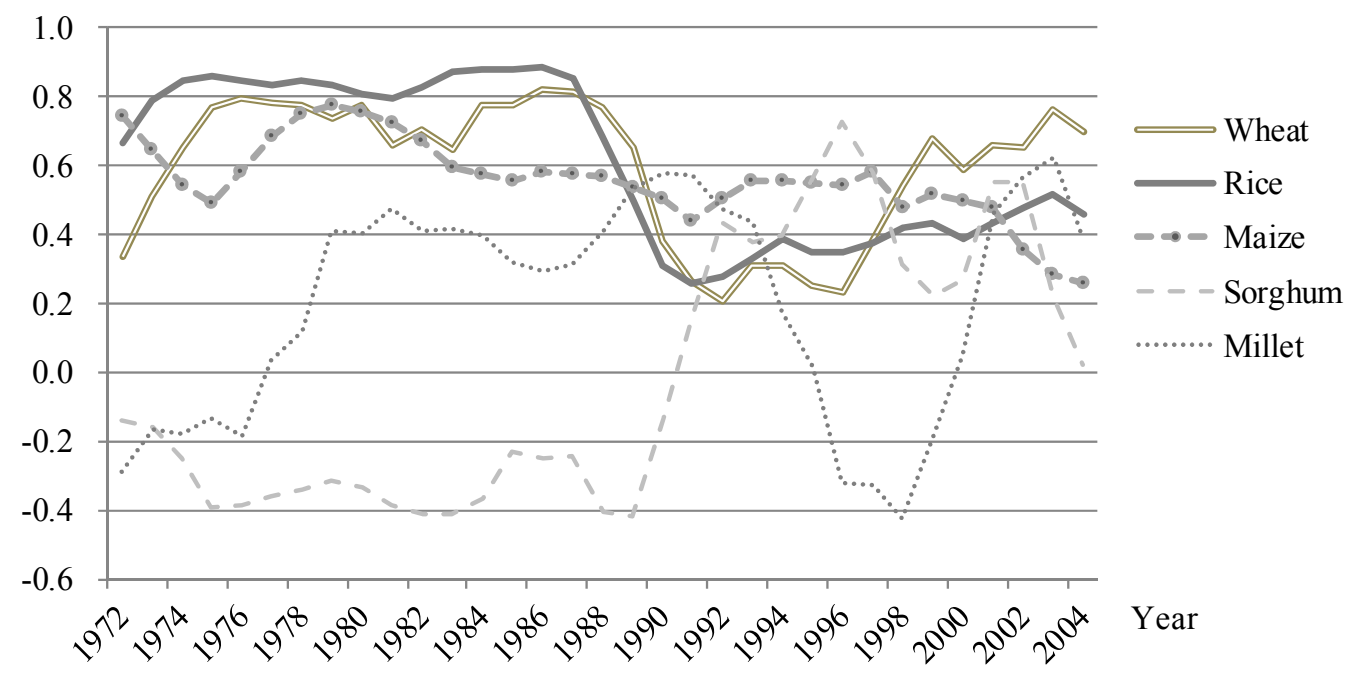

\begin{tabular}{|c|c|c|c|c|c|c|}
\hline & & Wheat & Rice & Maize & Sorghum & Millet \\
\hline \multirow{2}{*}{ Period Average } & $1974-1988$ & 0.76 & 0.79 & 0.62 & -0.27 & 0.30 \\
\hline & 1989-2002 & 0.38 & 0.35 & 0.46 & -0.08 & 0.09 \\
\hline
\end{tabular}

Figure 6. Coefficient of correlation between modern variety adoption rate and irrigation coverage rate, state-wise, by crop, three-year moving averages

Source: Authors' calculation with data from Indiastat and Center for Monitoring Indian Economy. 


\subsection{Estimation with the Proxy}

Tables $4 \mathrm{a}$ and $4 \mathrm{~b}$ show the estimation results for the yield functions of wheat, rice, and maize for the early stage of the GR, i.e., 1974 to 1988, using irrigation as the proxy variable. In contrast to the specification of yield equations for the whole period, the squared term of the time trend variable may be dispensed with, because the period is now shortened by a half and, hence, it should be reasonable to assume a linear effect of the time trend.

Judging from the negative and highly significant effect of the rainfall-irrigation interaction term for rice in both specifications, the dependence of rice yield on rainfall is likely to be lower in districts with higher MV adoption rates. Also, for wheat, the coefficients on the temperature-irrigation interaction term suggest a declining impact of temperature due to the adoption of wheat MVs combined with irrigation. When the adoption rate of the MV-irrigation technology package increases by 10 percentage points, the temperature effect on wheat yield decreases by 0.005 (percentage points per centigrade) and the rainfall elasticity of rice yield decreases by 0.04 .

The interaction terms with the time trend variable show that the temperature effect on wheat and rice yields, the rainfall effect on wheat yield, and the temperature effect on maize yield decline over time, indicating that some technological progress that is not simply captured by MV adoption rate and irrigation rate contributes to the reduction in the climate dependence of crop yields.

In any case, based on the assumption that the irrigation coverage variable acts as a proxy variable representing the adoption rate of MVs of wheat, rice, and maize as far as the earlier stage of the GR is concerned, these results suggest that technological progress that took place in conjunction with irrigation availability led to a reduced dependence of wheat yield on temperature and of rice yield on rainfall, whereas management practices and other factors unrelated to MV technology also seem to have contributed to a reduction in the climate effects on wheat, rice, and maize yields. Therefore, although the early stage GR technology is commonly considered as resource-using compared with the later-stage technology, it is suggested that even the technological changes in the early-stage GR can help mitigate the impact of climatic conditions on crop yields within the existing range of temperature and rainfall.

Furthermore, comparison between the result from section 4 and that from section 5 provides a meaningful insight. The coefficient on the temperature-irrigation interaction term in the wheat yield equation is $0.036(m=1)$ or $0.024(m=2$; at 12 percent significance level) in section 4 , and $0.048(m=1)$ or $0.053(m=2)$ in section 5 . The gap is certainly attributed to the fact that we observe the contribution of irrigation alone basically in section 4 , while section 5 examines the compound effect of irrigation and MV. Likewise, in the case of the rainfall-irrigation interaction term in the rice yield function, the coefficient is $-0.15(m=1)$ or $-0.13(m=2)$ in section 4 , and $-0.42(m=1)$ or $-0.40(m=2)$ in section 5 , indicating the remarkable contribution of MV adoption to mitigating the impact of rainfall on rice yield (Note 21). 
Table 4a. Estimation of Yield Equations for Wheat and Rice, 1974 to 1988

\begin{tabular}{|c|c|c|c|c|}
\hline \multirow{2}{*}{$\begin{array}{l}\text { Dependent Variable: } \\
\text { Ln Yield } \\
\text { Specification }\end{array}$} & \multicolumn{2}{|c|}{ Wheat } & \multicolumn{2}{|c|}{ Rice } \\
\hline & $m=1$ & $m=2$ & $m=1$ & $m=2$ \\
\hline District Effect & $\mathrm{FE}$ & $\mathrm{FE}$ & $\mathrm{FE}$ & FE \\
\hline Temperature & $\begin{array}{l}-0.0174 \\
(0.0301)\end{array}$ & $\begin{array}{l}-2.1856^{* * *} \\
(0.5027)\end{array}$ & $\begin{array}{c}0.0953^{* * *} \\
(0.0388)\end{array}$ & $\begin{array}{l}-1.0491 \\
(0.6764)\end{array}$ \\
\hline$(\text { Temperature })^{2}$ & & $\begin{array}{c}0.0428 * * * \\
(0.0099)\end{array}$ & & $\begin{array}{l}0.0224^{*} \\
(0.0132)\end{array}$ \\
\hline Temperature $\times \mathrm{t}$ & $\begin{array}{c}-0.0057 * * * \\
(0.0012)\end{array}$ & $\begin{array}{c}0.1359 * * * \\
(0.0266)\end{array}$ & $\begin{array}{c}-0.0043 * * * \\
(0.0016)\end{array}$ & $\begin{array}{c}0.1000 * * * \\
(0.0353)\end{array}$ \\
\hline$(\text { Temperature })^{2} \times t$ & & $\begin{array}{c}-0.0028 * * * \\
(0.0005)\end{array}$ & & $\begin{array}{c}-0.0021 * * * \\
(0.0007)\end{array}$ \\
\hline Temperature $\times$ Irrigation Coverage & $\begin{array}{l}0.0476^{*} \\
(0.0289)\end{array}$ & $\begin{array}{c}0.0534 * * \\
(0.0288)\end{array}$ & $\begin{array}{l}-0.0651 \\
(0.0439)\end{array}$ & $\begin{array}{l}-0.0615 \\
(0.0439)\end{array}$ \\
\hline Ln Rainfall & $\begin{array}{c}0.2030^{* * * *} \\
(0.0471)\end{array}$ & $\begin{array}{l}-0.1538 \\
(0.3199)\end{array}$ & $\begin{array}{c}0.5729 * * * \\
(0.0579)\end{array}$ & $\begin{array}{c}1.5868 * * * \\
(0.4872)\end{array}$ \\
\hline$(\text { Ln Rainfall })^{2}$ & & $\begin{array}{c}0.0268 \\
(0.0228)\end{array}$ & & $\begin{array}{c}-0.0742 * * \\
(0.0353)\end{array}$ \\
\hline Ln Rainfall $\times \mathrm{t}$ & $\begin{array}{c}-0.0127 * * * \\
(0.0026)\end{array}$ & $\begin{array}{c}0.0244 \\
(0.0208)\end{array}$ & $\begin{array}{l}-0.0040 \\
(0.0038)\end{array}$ & $\begin{array}{l}-0.0645^{*} \\
(0.0349)\end{array}$ \\
\hline$(\text { Ln Rainfall })^{2} \times \mathrm{t}$ & & $\begin{array}{c}-0.0031 * * \\
(0.0016)\end{array}$ & & $\begin{array}{l}0.0043^{*} \\
(0.0026)\end{array}$ \\
\hline Ln Rainfall × Irrigation Coverage & $\begin{array}{l}-0.0536 \\
(0.0426)\end{array}$ & $\begin{array}{l}-0.0402 \\
(0.0455)\end{array}$ & $\begin{array}{c}-0.4169 * * * \\
(0.0462)\end{array}$ & $\begin{array}{c}-0.3953 * * * \\
(0.0471)\end{array}$ \\
\hline Irrigation Coverage for Each Crop & $\begin{array}{l}-0.5556 \\
(0.8053)\end{array}$ & $\begin{array}{l}-0.7805 \\
(0.8108)\end{array}$ & $\begin{array}{c}4.7135^{* * * *} \\
(1.2279)\end{array}$ & $\begin{array}{c}4.4503 * * * \\
(1.2290)\end{array}$ \\
\hline Irrigation Coverage $\times \mathrm{t}$ & $\begin{array}{l}-0.0062 \\
(0.0052)\end{array}$ & $\begin{array}{l}-0.0066 \\
(0.0053)\end{array}$ & $\begin{array}{c}0.0044 \\
(0.0055)\end{array}$ & $\begin{array}{c}0.0081 \\
(0.0057)\end{array}$ \\
\hline Literacy Rate & $\begin{array}{l}1.1009 * * \\
(0.5594)\end{array}$ & $\begin{array}{c}0.3878 \\
(0.5685)\end{array}$ & $\begin{array}{c}1.2269 \\
(0.8625)\end{array}$ & $\begin{array}{c}0.7182 \\
(0.8766)\end{array}$ \\
\hline Literacy Rate $\times \mathrm{t}$ & $\begin{array}{c}-0.0538^{* * * *} \\
(0.0151)\end{array}$ & $\begin{array}{l}-0.0292^{*} \\
(0.0156)\end{array}$ & $\begin{array}{l}-0.0382^{*} \\
(0.0209)\end{array}$ & $\begin{array}{l}-0.0257 \\
(0.0215)\end{array}$ \\
\hline Ln Population Density & $\begin{array}{c}0.2507 \\
(0.3302)\end{array}$ & $\begin{array}{l}0.6090 * \\
(0.3343)\end{array}$ & $\begin{array}{c}1.8484 * * * \\
(0.4446)\end{array}$ & $\begin{array}{c}1.9945 * * * \\
(0.4543)\end{array}$ \\
\hline Ln Population Density $\times \mathrm{t}$ & $\begin{array}{l}0.0032 * \\
(0.0019)\end{array}$ & $\begin{array}{c}0.0026 \\
(0.0020)\end{array}$ & $\begin{array}{l}-0.0013 \\
(0.0027)\end{array}$ & $\begin{array}{l}-0.0009 \\
(0.0027)\end{array}$ \\
\hline Inverse Mills Ratio & $\begin{array}{c}-0.2064 * * \\
(0.0893)\end{array}$ & $\begin{array}{c}-0.1951^{* *} \\
(0.0887)\end{array}$ & $\begin{array}{c}-0.5591^{* * * *} \\
(0.1269)\end{array}$ & $\begin{array}{c}-0.5584 * * * \\
(0.1274)\end{array}$ \\
\hline $\mathrm{t}$ & $\begin{array}{c}0.2531 * * * \\
(0.0400)\end{array}$ & $\begin{array}{c}-1.6296 * * * \\
(0.3417)\end{array}$ & $\begin{array}{l}0.1299 * * \\
(0.0545)\end{array}$ & $\begin{array}{c}-0.9870 * * \\
(0.4699)\end{array}$ \\
\hline Constant Term & $\begin{array}{c}4.1375^{* *} \\
(1.7885)\end{array}$ & $\begin{array}{c}31.1039 * * * \\
(6.5825)\end{array}$ & $\begin{array}{c}-9.6467 * * * \\
(2.4464)\end{array}$ & $\begin{array}{c}0.9216 \\
(8.9810)\end{array}$ \\
\hline Number of Observations & & & & \\
\hline R-squared: Overall & 0.2456 & 0.1897 & 0.1222 & 0.1166 \\
\hline Hausman Test & & & & \\
\hline $\begin{array}{l}\chi^{2} \text { statistics (degrees of freedom) } \\
\text { Prob }>\chi^{2}\end{array}$ & $\begin{array}{l}71.55(25) \\
0.0000\end{array}$ & $\begin{array}{c}-38.14(28) \\
\mathrm{n} / \mathrm{a}\end{array}$ & $\begin{array}{c}104.57(26) \\
0.0000\end{array}$ & $\begin{array}{l}108.94(28) \\
0.0000\end{array}$ \\
\hline
\end{tabular}

$* * *, * *$, and $*$ indicate 1 percent, 5 percent, and 10 percent statistical significance levels, respectively.

Standard errors are in the parentheses.

Notes: (1) In this estimation for the early stage GR, irrigation coverage variable is used as a technology adoption indicator. (2) The logarithm of temperature is mathematically inappropriate unless it is a Kelvin measure. See also section 3.3 . 
Table 4b. Estimation of Yield Equations for Maize, 1974 to 1988

\begin{tabular}{|c|c|c|}
\hline $\begin{array}{l}\text { Dependent Variable: } \\
\text { Ln Yield }\end{array}$ & \multicolumn{2}{|c|}{ Maize } \\
\hline Specification & $m=1$ & $m=2$ \\
\hline District Effect & $\mathrm{FE}$ & $\mathrm{RE}$ \\
\hline Temperature & $\begin{array}{l}0.0829 * * \\
(0.0415)\end{array}$ & $\begin{array}{c}-1.8970^{* * *} \\
(0.5446)\end{array}$ \\
\hline${\text { (Temperature })^{2}}^{2}$ & & $\begin{array}{c}0.0384 * * * \\
(0.0108)\end{array}$ \\
\hline Temperature $\times \mathrm{t}$ & $\begin{array}{c}0.0006 \\
(0.0019)\end{array}$ & $\begin{array}{c}0.1589 * * * \\
(0.0404)\end{array}$ \\
\hline$(\text { Temperature })^{2} \times t$ & & $\begin{array}{c}-0.0031 * * * \\
(0.0008)\end{array}$ \\
\hline Temperature $\times$ Irrigation Coverage & $\begin{array}{c}0.0382 \\
(0.0453)\end{array}$ & $\begin{array}{l}0.0000 \\
(0.0384)\end{array}$ \\
\hline Ln Rainfall & $\begin{array}{c}0.0450 \\
(0.0609)\end{array}$ & $\begin{array}{c}0.2507 \\
(0.4949)\end{array}$ \\
\hline$(\text { Ln Rainfall })^{2}$ & & $\begin{array}{l}-0.0086 \\
(0.0363)\end{array}$ \\
\hline Ln Rainfall $\times \mathrm{t}$ & $\begin{array}{c}0.0059 \\
(0.0042)\end{array}$ & $\begin{array}{c}0.0087 \\
(0.0346)\end{array}$ \\
\hline$(\text { Ln Rainfall })^{2} \times \mathrm{t}$ & & $\begin{array}{l}-0.0007 \\
(0.0026)\end{array}$ \\
\hline Ln Rainfall $\times$ Irrigation Coverage & $\begin{array}{c}0.0100 \\
(0.0533)\end{array}$ & $\begin{array}{l}0.0312 \\
(0.0526)\end{array}$ \\
\hline Irrigation Coverage for Each Crop & $\begin{array}{l}-1.0868 \\
(1.2794)\end{array}$ & $\begin{array}{l}-0.0808 \\
(1.0862)\end{array}$ \\
\hline Irrigation Coverage $\times \mathrm{t}$ & $\begin{array}{l}0.0125^{*} \\
(0.0075)\end{array}$ & $\begin{array}{c}0.0201 * * * \\
(0.0075)\end{array}$ \\
\hline Literacy Rate & $\begin{array}{l}1.5523 \\
(1.1173)\end{array}$ & $\begin{array}{c}1.8720 * * * \\
(0.3724)\end{array}$ \\
\hline Literacy Rate $\times \mathrm{t}$ & $\begin{array}{c}-0.1045 * * * \\
(0.0276)\end{array}$ & $\begin{array}{c}-0.0939 * * * \\
(0.0240)\end{array}$ \\
\hline Ln Population Density & $\begin{array}{c}0.0345 \\
(0.5403)\end{array}$ & $\begin{array}{c}-0.1096 * * \\
(0.0465)\end{array}$ \\
\hline Ln Population Density $\times \mathrm{t}$ & $\begin{array}{c}0.0118 * * * \\
(0.0033)\end{array}$ & $\begin{array}{c}0.0095 * * * \\
(0.0033)\end{array}$ \\
\hline Inverse Mills Ratio & $\begin{array}{c}0.0836 \\
(0.2400)\end{array}$ & $\begin{array}{l}-0.0611 \\
(0.2215)\end{array}$ \\
\hline $\mathrm{t}$ & $\begin{array}{l}-0.0824 \\
(0.0657)\end{array}$ & $\begin{array}{c}-2.0735^{* * * *} \\
(0.5215)\end{array}$ \\
\hline Constant Term & $\begin{array}{l}3.5215 \\
(2.8561)\end{array}$ & $\begin{array}{l}28.6166^{* * * *} \\
(7.0890)\end{array}$ \\
\hline Number of Observations & & \\
\hline R-squared: Overall & 0.1454 & 0.2616 \\
\hline Hausman Test & & \\
\hline $\begin{array}{l}\chi^{2} \text { statistics (degrees of freedom) } \\
\text { Prob }>\chi^{2}\end{array}$ & $\begin{array}{l}64.93(26) \\
0.0000\end{array}$ & $\begin{array}{c}19.36(28) \\
0.8867\end{array}$ \\
\hline
\end{tabular}

$* * *, * *$, and * indicate 1 percent, 5 percent, and 10 percent statistical significance levels, respectively.

Standard errors are in the parentheses.

Notes: (1) Irrigation coverage is used as a technology adoption indicator. (2) The logarithm of temperature is mathematically inappropriate. See also section 3.3.

\section{Concluding Remarks}

Although it is well-known that the GR enormously contributed to the growth in crop yields in Asia, it is much less known whether it mitigated or augmented the impacts of agro-climatic conditions on crop yields. This study attempted to provide evidence on the changing impacts of temperature, rainfall, and irrigation on cereal crop yields in India through econometric analyses employing a district-level panel data set that covers the recent three decades.

First, it is revealed that the dependence of crop yields on climatic conditions changes over time in many cases. Particularly in recent years, climate dependence decreases, indicating that the adoption of relatively new technologies contributed to mitigating, rather than aggravating, the adverse effects of unfavorable climatic conditions on crop yields in India. As for rice, sorghum, and millet, the predicted temperature effect decreases 
throughout the period, whereas as for maize it increases until 1992 and then decreases thereafter. The dependence of crop yields on rainfall also decreases over time, for wheat, rice, and sorghum. These results suggest that crop yields have been affected less by climatic conditions over time, even after taking into account the influence of irrigation diffusion. Therefore, the results support our hypothesis that the improved traits of relatively recent MVs have contributed to alleviating, not aggravating, the influence of climatic conditions, which is in sharp contrast to the commonly accepted wisdom that MVs, particularly in the early stage of the GR, were typically resource-demanding technologies and were higher-yielding only under favorable production environments. (Note 22) A possible mechanism is that varieties with short maturities can grow up in a shortened period during which rainfall is assured. It is also important to point out that improved drought tolerance contributes to reducing downward yield risk, which leads to a decrease in the marginal effect in the low range of rainfall. Moreover, the result for the temperature effect on maize yield indicates that early generations of maize MVs tend to aggravate the adverse effect of low temperature, whereas subsequent generations are more suitable to unfavorable conditions. Furthermore, on top of these changes over time, the extended analysis using the proxy variable for MV adoption rate confirmed that when the adoption rate of the MV-irrigation technology package increases by 10 percentage points, the temperature effect on wheat yield decreases by 0.005 (percentage points per degree), and the rainfall elasticity of rice yield decreases by 0.04 . Comparison with the effect of irrigation that is unpackaged with MV indicates that the contribution of MV itself was also significant.

Second, as would be expected, irrigation plays a considerably important role in achieving higher yields of wheat, rice, and sorghum in India. In analogy with the temperature effect on maize yield, the irrigation effect on rice yield exhibits an inverted U-like change over time, indicating that the older MVs of rice require more irrigation water than the TVs, while the newer MVs of rice require less irrigation water than the older MVs. This resource saving nature of recent rice MV technology deserves due attention as such a trait would promote the diffusion of modern rice technology in regions under less favorable climatic conditions. Further, it is important to recognize that irrigation contributes not only to increasing yields directly but also to mitigating the impacts of temperature and rainfall on crop yields in many cases. In the case of temperature, this applies to all five crops studied. The substitution relationship between rainfall and irrigation holds for wheat and rice, indicating that, for these two crops, irrigation can substitute for the role of rainfall.

Third, continued population pressure is likely to have increased the relative profitability of land-saving and yield-enhancing innovations and technologies along the lines of the induced innovation hypothesis proposed by Hayami and Ruttan (1985).

Lastly, with regard to technology transfer, Otsuka and Larson (2013) indicate transferability of some improved technologies from Asia to SSA. Moreover, biotechnology may offer considerable potential for improving the traits of recent MVs (Johnson et al., 2003; Ervin, 1999; US Congress, 1993). Since maize is the most widely cultivated crop in SSA, the productivity of maize farming must be enhanced. The advantage of maize is that its yield is not adversely affected by the unavailability of irrigation, meaning that maize has a comparative advantage in rain-fed farming systems. Yet, it must be recognized that, unlike rice, the maize varieties developed in Asia are not directly transferable to SSA. Sorghum and millet do not appear to be attractive crops in terms of technology transfer, given the absence of the yield difference between Asia and SSA even today, despite the much more favorable conditions of climate, infrastructure, markets, education, and governance in Asia. Therefore, new appropriate technologies for sorghum and millet must be developed rather than relying on technology transfer, in order to realize a GR for these crops.

\section{References}

Adams, R. M., Fleming, R. A., Chang, C., McCarl, B. A., \& Rosensweig, C. (1995). A Reassessment of the Economic Effects of Global Climate Change on U.S. Agriculture. Climate Change, 30, 147-167. http://dx.doi.org/10.1007/BF01091839

Anthony, C. G. (1988). Mechanization and Maize: Agriculture and the Politics of Technology Transfer in East Africa. Political Economy of International Change. New York: Columbia University Press.

Auffhammer, M., \& Ramanathan, V., \& Vincent, J. R. (2006). Integrated Model Shows that Atmospheric Brown Clouds and Greenhouse Gases Have Reduced Rice Harvests in India. Proceedings of the National Academy of Sciences, 103(52), 19668-19672. http://dx.doi.org/10.1073/pnas.0609584104

Bardhan, P. (1993). Symposium on Management of Local Commons. Journal of Economic Perspectives, 7(4), 87-92. http://dx.doi.org/10.1257/jep.7.4.87

Bardhan, P. (1995). Rational Fools and Co-operation in a Poor Hydraulic Economy. In K. Basu, P. Pattanaik, \& 
K. Suzumura (Eds.), Choice, Welfare, Development - A Festschrift in Honor of Amartya K. Sen. Oxford University Press.

Bhalla, G. S., \& Singh, G. (2001). Indian Agriculture: Four Decades of Development. New Delhi: Sage Publications.

Bruce, J. P., Yi, H., \& Haites, E. F. (1996). Climate Change 1995 - Economic and Social Dimensions of Climate Change. Cambridge: Cambridge University Press.

Byerlee, D. (1996). Modern Varieties, Productivity, and Sustainability: Recent Experience and Emerging Challenges. World Development, 24(4), 697-718. http://dx.doi.org/10.1016/0305-750X(95)00162-6

Byerlee, D., Diao, X., \& Jackson, C. (2005). Agriculture, Rural Development, and Pro-poor Growth: Country Experiences in the Post-Reform Era. Agriculture and Rural Development (ARD) Discussion Paper, 21. Washington, D. C.: World Bank.

Cavatassi, R., Lipper, L., \& Barloch, U. (2011). Modern Variety Adoption and Risk Management in Drought Prone Areas: Insights from the Sorghum Farmers of Eastern Ethiopia. Agricultural Economics, 42(3), 279-292. http://dx.doi.org/10.1111/j.1574-0862.2010.00514.x

Christiaensen, L. J., \& Demery, L. (2012). Down to Earth: Agriculture and Poverty Reduction in Africa, Directions in Development. Journal of Development Economics, forthcoming.

David, C. C., \& Otsuka, K. (1994). Modern Rice Technology and Income Distribution in Asia. Boulder: Lynne Rienner.

Deschênes, O., \& Greenstone, M. (2007). Climate Change, Mortality, and Adaptation: Evidence from Annual Fluctuations in Weather in the US. NBER Working Paper, 13178.

Ervin, D. E. (1999). Agricultural Biotechnology is a Double-edged Environmental Sword. Henry A. Wallace Institute, Remarks to the National Association of Agricultural Journalists, Washington, D.C.

Estudillo, J. P., \& Otsuka, K. (2013). The Evolution of the Rice Green Revolution in Asia and Its Transferability to Contemporary Sub-Saharan Africa. In O. Keijiro, \& L. Donald (Eds.), An African Green Revolution: Finding Ways to Boost Productivity on Small Farms (Chapter 2), Washington D.C.: World Bank, forthcoming.

Fan, S., \& Hazell, P. B. R. (1999). Are Returns to Public Investment Lower in Less-Favored Rural Areas? An Empirical Analysis of India. EPTD Discussion Paper, 43.

Fan, S., Hazell, P. B. R., \& Thorat, S. (2000). Government Spending, Growth, and Poverty in Rural India. American Journal of Agricultural Economics, 82(4), 1038-1051. http://dx.doi.org/10.1111/0002-9092.00101

Fujisaka, S., Harrington, L., \& Hobbs, P. (1994). Rice-Wheat in South Asia: Systems and Long-term Priorities Established Through Diagnostic Research. Agricultural Systems, 46(2), 169-187. http://dx.doi.org/10.1016/0308-521X(94)90096-X

Fujita, K. (2010). The Green Revolution and Its Significance for Economic Development. The Indian Experience and Its Implications for Sub-Saharan Africa. Japan International Cooperation Agency Research Institute Working Paper, 17.

Gollin, D. (2006). Impacts of International Research on Intertemporal Yield Stability in Wheat and Maize: An Economic Assessment. Mexico, D.F.: CIMMYT (International Maize and Wheat Improvement Center).

Hausman, J. A. (1978). Specification Tests in Econometrics. Econometrica, 46(6), 1251-1271. http://dx.doi.org/10.2307/1913827

Hayami, Y., \& Godo, Y. (2005). Strategies and Conditions for Development - from the Poverty to the Wealth of Nations. Oxford University Press.

Hayami, Y., \& Ruttan, V. W. (1985). Agricultural Development: An International Perspective. Baltimore: Johns Hopkins University Press.

Hazell, P. B. R. (2001). Agriculture and Environment. Environment and Development Economics, 6(2001), 503-531. http://dx.doi.org/10.1017/S1355770X01250281

Heckman, J. J. (1979). Sample Selection Bias as a Specification Error. Econometrica, 47, 153-161. http://dx.doi.org/10.2307/1912352

Hossain, M., \& Fischer, K. S. (1995). Rice Research for Food Security and Sustainable Agricultural 
Development in Asia: Achievements and Future Challenges. Geo Journal, 35(3), 286-298. http://dx.doi.org/10.1007/BF00989136

Janaiah, A., Achoth, L., \& Bantilan, C. (2005). Has the Green Revolution Bypassed Coarse Cereals? The Indian Experience. e-Journal of Agricultural and Development Economics, 2(1), 20-31.

Janaiah, A., Hossain, M., \& Otsuka, K. (2006). Productivity Impact of the Modern Varieties of Rice in India. The Developing Economies, XLIV-2(June 2006), 190-207. http://dx.doi.org/10.1111/j.1746-1049.2006.00013.x

Johnson, M., Hazell, P. B. R., \& Gulati, A. (2003). The Role of Intermediate Factor Markets in Asia's Green Revolution: Lessons for Africa? American Journal of Agricultural Economics, 85(5), 1211-1216. http://dx.doi.org/10.1111/j.0092-5853.2003.00532.x

Khush, G. S. (2001). Green Revolution: The Way Forward. Nature Reviews: Genetics, October, 2001(2), 815-822. http://dx.doi.org/10.1038/35093585

Kuyvenhoven, A. (2008). Africa, Agriculture, Aid. National Journal of Agricultural Science, 55(2), 93-112.

Lam, W. F. (1996). Improving the Performance of Small-Scale Irrigation Systems: The Effects of Technological Investments and Governance Structure on Irrigation Performance in Nepal. World Development, 24(8), 1301-1315. http://dx.doi.org/10.1016/0305-750X(96)00043-5

Lawn, R. J. (1989). Agronomic and Physiological Constraints to the Productivity of Tropical Grain Legumes and

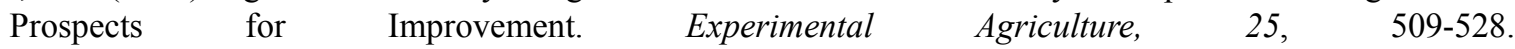
http://dx.doi.org/10.1017/S0014479700015143

Lipton, M. (2007). Plant Breeding and Poverty: Can Transgenic Seeds Replicate the 'Green Revolution' as a Source of Gains for the Poor? Journal of Development Studies, 43(1), 31-62. http://dx.doi.org/10.1080/00220380601055510

Lipton, M., \& Longhurst, R. (1989). New Seeds and Poor People. London: Unwin Hyman. http://dx.doi.org/10.1080/00220380601055510

Olesen, J. E., \& Bindi, M. (2002). Consequences of Climate Change for European Agricultural Productivity, Land Use and Policy. European Journal of Agronomy, 16(4), 239-262. http://dx.doi.org/10.1016/S1161-0301(02)00004-7

Ostrom, E. (1990). Governing the Commons: the Evolution of Institutions for Collective Action. Cambridge: Cambridge University Press. http://dx.doi.org/10.1017/CBO9780511807763

Otsuka, K., Estudillo, J. P., \& Sawada, Y. (2009). Rural Poverty and Income Dynamics in Asia and Africa. London: Routledge.

Otsuka, K., \& Kalirajan, K. (2006). Rice Green Revolution in Asia and Its Transferability to Africa: An Introduction. Developing Economies, XLIV-2, 107-122. http://dx.doi.org/10.1111/j.1746-1049.2006.00009.x

Otsuka, K., \& Larson, D. F. (2013). An African Green Revolution: Finding Ways to Boost Productivity on Small Farms. Amsterdam: Springer. http://dx.doi.org/10.1007/978-94-007-5760-8

Otsuka, K., \& Yamano, T. (2005). The Possibility of a Green Revolution in Sub-Saharan Africa: Evidence from Kenya. Journal of Agricultural and Development Economics, 2(1), 8-19.

Pray, C. E., \& Nagarajan, L. (2010). Pearl Millet and Sorghum Improvement in India. In D. J. Spielman \& R. Pandya-Lorch (Eds.), Proven Successes in Agricultural Development: A Technical Compendium to Millions Fed. Washington, D.C.: International Food Policy Research Institute (IFPRI).

Reilly, J., Baethgen, W., Chege, F. E., van de Geijn, S., Enda, L., Iglesias, A., ... Howden, M. (1996). Agriculture in a Changing Climate: Impacts and Adaptation. Climate Change 1995: Impacts, Adaptations and Mitigation of Climate Change: Scientific-Technical Analysis: 427-468.

Rosegrant, M. W., \& Hazell, P. B. R. (2000). Transforming the Rural Asian Economy: The Unfinished Revolution. Hong Kong: Oxford University Press for the Asian Development Bank.

Rozeboom, W. W. (1966). Scaling Theory and the Nature of Measurement. Synthese, 16, 170-233. http://dx.doi.org/10.1007/BF00485356

Sanghi, A., Mendelsohn, R. O., \& Dinar, A. (1998). The Climate Sensitivity of Indian Agriculture. In D. Ariel, O. Mendelsohn Robert, R. E. Evenson, J. Parikh, A. Sanghi, K. Kumar, ... Lonergan Stephen (Eds.), Measuring the Impact of Climate Change on Indian Agriculture. World Bank Technical Paper 402. 
Schlenker, W., \& Roberts, M. J. (2006). Nonlinear Effects of Weather on Corn Yields. Review of Agricultural Economics, 28(3), 391-398. http://dx.doi.org/10.1111/j.1467-9353.2006.00304.x

Seabright, P. (1993). Managing Local Commons: Theoretical Issues in Incentive Design. Journal of Economic Perspectives, 7(4), 113-134. http://dx.doi.org/10.1257/jep.7.4.113

Seo, N., \& Mendelsohn, R. O. (2007). A Ricardian Analysis of the Impact of Climate Change on Latin American Farms. World Bank Policy Research Working Paper 4163.

Singh, A. K., \& Jain, G. L. (2000), Effect of Sowing Time, Irrigation and Nitrogen on Grain Yield and Quality of Durum Wheat (Triticum durum). Indian Journal of Agricultural Sciences, 70(8), 532-533.

Spencer, D. S. C. (1994). Infrastructure and Technology Constraints to Agricultural Development in the Humid and Sub-humid Tropics of Africa. Environmental and Production Technology Division (EPTD) Discussion Paper 3, International Food Policy Research Institute (IFPRI).

Stevens, S. S. (1946). On the Theory of Scales of Measurement. Science, 103, 677-680. http://dx.doi.org/10.1126/science.103.2684.677

Tsusaka, T., \& Otsuka, K. (2013a). The Impact of Technological Change on Crop Yields in Sub-Saharan Africa, 1967 to 2004. In Otsuka, K., \& Larson, D. F. (Eds.), An African Green Revolution: Finding Ways to Boost Productivity on Small Farms (Chapter 5), Amsterdam: Springer.

Tsusaka T., \& Otsuka, K. (2013b). The Changes in the Effects of Temperature and Rainfall on Cereal Crop Yields in Sub-Saharan Africa: A Country Level Panel Data Study, 1989 to 2004. mimeo.

U.S. Congress, Office of Technology Assessment (OTA). (1993). Harmful Non-indigenous Species in the United States. OTA-F-566. Washington, D.C.: Government Printing Office.

World Bank. (2008). World Development Report. Washington, D.C.: World Bank.

Yen, S. T. (2005). A Multivariate Sample-Selection Model: Estimating Cigarette and Alcohol Demands with Zero Observations. American Journal of Agricultural Economics, 87(2), 453-66. http://dx.doi.org/10.1111/j.1467-8276.2005.00734.x

\section{Notes}

Note 1. Aside from climatic factors, other causes for the failure of a GR in SSA include the low availability of irrigation, insufficient fertilizer usage, soil degradation in some areas, under-developed infrastructure, poor governance and coordination, inaccessibility to markets, lack of agricultural credit and education (Kuyvenhoven, 2008; Hayami \& Godo, 2005; Spencer, 1994; David \& Otsuka, 1994).

Note 2. Apart from the GR, in eastern and southern Africa, the first half of the 20th century saw the emergence of maize as a dominant staple crop to replace sorghum and millet partly because maize yielded more grain under favorable conditions than did sorghum and millet (Anthony 1988).

Note 3. Facing the failure of the management of government-driven irrigation schemes, some studies in the 1990s emphasize the ability of the community to manage irrigation schemes (Bardhan, 1993; Lam, 1996; Seabright, 1993).

Note 4. Cavatassi et al. (2011) found in eastern Ethiopia that the early-maturing sorghum MVs adopted at their study site can cope with downward yield risks associated with moderate droughts, while the TVs (traditional varieties) are actually more tolerant of extreme drought events.

Note 5. We have also tried the estimations using seasonal climate (kharif and rabi), of which the result did not seem clear. One reason may be the variability in planting timing, due to which the relevant climate input is not entirely covered by a seasonal variable. This must be even more so in earlier years when crop growth duration was generally longer. Another reason may be the practice of dual cropping which would require consideration of almost year-round climate data, particularly in recent years when shorter growth duration facilitates dual cropping practices.

Note 6. For population and literacy rate, temporal interpolation is used as needed.

Note 7. India now comprises as many as 600 districts; the number has been steadily increasing as more and more districts have declared independence. Hence, combining the data from different sources in a consistent manner over the long term is not straightforward. As far as simple mergers and separations are concerned, the data can be adjusted by arithmetic operations, in which post-merger or pre-separation district bordering 
is adopted so as to construct a consistent long-term panel. Otherwise, we used temporal interpolation and extrapolation techniques.

Note 8. Hitherto we have received comments from several peer economists suggesting estimations without a sample selection model since the fixed/random effects model for the yield equations would largely mitigate the selection bias. Yet, this paper still employs a two-step approach because the period of 31 years may not be short enough for the district effect model to control for the bias.

Note 9. Note that a multiple choice equation such as multinomial logit cannot be applied to our case, because it is not just one crop that is chosen out of the five crops under study; i.e., the five crops are not mutually exclusively chosen. In fact, since it is district-level data, as opposed to farm level, more than one crop are chosen in most observations (districts and years). To force to use multinomial logit, there would be $32\left(=2^{5}\right)$ mutually exclusive choices to be considered, which is not practically feasible. Incidentally, if this were a farm household or individual level analysis (i.e., microeconometrics), we would employ the multivariate sample selection model studied by Yen (2005) which allows correlations between the error term of crop A's selection equation and the error term of crop B's outcome equation.

Note 10. Regarding normal climate, we also used five-year moving averages to check the robustness. The results are largely the same. The shortcoming of using a longer period is that it leads to a reduced number of observations.

Note 11. Note that it is an irrigation ratio accounting for all crops, and therefore different from the crop-specific irrigation ratio included in the second step outcome equations.

Note 12. The population density refers to the total district population divided by the total district area.

Note 13. The endogeneity of district-level irrigation coverage may arise in cross-sectional regression analyses. However, the introduction of such irrigation, whether it is gravity or tubewell, tends to be influenced by some unobservable district-specific topographical and climatic characteristics that are essentially constant over time, in addition to the observable climatic factors. The district-level fixed (or random) effect model, which controls for unobservable time-invariant district-specific effects, should largely mitigate the potential endogeneity bias in the irrigation effect, if any.

Note 14. Note that the time trend variables and the year dummies can both be included in the model, where the former captures a relatively smooth trend in yield growth and the latter captures aggregate fluctuations in yield every year. Practically, the controlling effect does not differ whether we include only the dummies or both.

Note 15. They hypothesize that the increasing scarcity of land induces the development and diffusion of land-saving and yield-enhancing innovations as the marginal product of labor approaches zero. The innovations include both technological changes and increased inputs due to better access to markets. Yet, the regression results are not capable of formally proving the hypothesis, as a positive effect could simply indicate a positive marginal product of labor.

Note 16. When the Hausman test fails and returns a negative $\chi^{2}$ statistic, we opt for the fixed effect model to be safe, as the fixed effect estimators are always consistent even if not efficient.

Note 17. Although in the specification $m=2$ the coefficient on the temperature-irrigation interaction term appears statistically insignificant, it is actually nearly significant at the 12 percent level.

Note 18. According to Cavatassi et al. (2011), the sorghum MVs adopted in eastern Ethiopia have early-maturing traits and thus can better cope with the downward yield risks associated with moderate droughts.

Note 19. Note that this decrease over time in the total temperature effect stems from the changes over time in the average irrigation coverage rate for a millet field via the temperature-irrigation interaction term, not directly from the temperature-time trend interaction terms.

Note 20. The total irrigation effect on millet yield is extremely sensitive to the coefficient on the temperature-irrigation interaction term, so that even a small difference in that coefficient between the two specifications leads to a visible difference in the total irrigation effect.

Note 21. Although unreported here, the estimation results for the later period were also examined, in which the irrigation variable is no longer considered as a proxy for the MV-irrigation technology package. The effect of irrigation seems to be weaker than it is for the earlier period. However, this does not suggest much about the impact of MV adoption, as the two variables are no longer highly correlated. 
Note 22. Declining effects of climate during the studied period are not necessarily observed across the world. For instance, Tsusaka and Otsuka (2013b) find that in SSA from 1989 to 2004, the temperature effect is mitigated for maize and aggravated for millet, while the rainfall dependency declined for rice and was augmented for wheat and maize, suggesting that technology effects are different at different phases of technological development. 